\title{
DEVELOPMENT OF NOVEL ANTI-MICROBIAL PLANT ESSENTIAL-OIL TREATMENTS TO REDUCE THE POSTHARVEST INCIDENCE OF BOTRYTIS CINEREA OF STRAWBERRIES
}

\author{
A Thesis \\ presented to \\ the Faculty of California Polytechnic State University, \\ San Luis Obispo \\ In Partial Fulfillment \\ of the Requirements for the Degree \\ Master of Science in Agriculture
}

by

Ryan Christopher Brantley

June 2014 
(C) 2014

Ryan Christopher Brantley

ALL RIGHTS RESERVED 


\section{COMMITTEE MEMBERSHIP}

TITLE:

Development of Novel Anti-Microbial Plant Essential-

Oil treatments to Reduce the Postharvest Incidence of

Botrytis cinerea of Strawberries

AUTHOR: $\quad$ Ryan C. Brantley

DATE SUBMITTED: June 2014

COMMITTEE CHAIR: J. Wyatt Brown, PhD

Professor of Horticulture and Crop Science

COMMITTEE MEMBER: $\quad$ Lauren Garner, PhD

Professor of Horticulture and Crop Science

COMMITTEE MEMBER: Jennifer Carroll, PhD

Associate Professor of Chemistry 


\section{ABSTRACT \\ Development of Novel Anti-Microbial Plant Essential-Oil treatments \\ To Reduce the Postharvest Incidence of \\ Botrytis cinerea of Strawberries \\ Ryan Christopher Brantley}

Fresh strawberries have grown into a multi-billion dollar industry over the last few decades in California. Botrytis cinerea or grey mold, is the worst pathological disorder affecting strawberry fruit causing cull rates of up to $30 \%$ in the worst seasons. Strawberry fruits are fragile and have a short shelf-life making timely harvest, cooling, and marketing an absolute necessity. The current industry standard is to ship strawberries in an overwrapped $\mathrm{CO}_{2}$-enriched headspace pallet in refrigerated trucks at $33^{\circ} \mathrm{F}$.

However, B. cinerea has the ability to grow at very low temperatures and continues to plague the strawberry industry during postharvest storage and retail sale.

Postharvest treatments available for strawberry preservation and disease management have been severely limited due to the reluctance to spray or wash the fruit. Consumers are also demanding produce that is free from synthetic chemical residues. Recent research with plant essential-oil volatile compounds has indicated that they have significant anti-fungal activity. Very little information is available regarding the use of essential-oil compounds for postharvest treatments on California strawberries to reduce the incidence of $B$. cinerea. The primary objective of this study was to investigate the potential for synergy to control $B$. cinerea through the combined application of volatile treatment constituents with uniquely different modes of action. 
Strawberries were acquired from commercial growers in the Santa Maria area of California on the day of harvest. Volatile essential-oil compounds were diluted in ethanol and applied to sachets which were then affixed to the inner lids of randomly selected clamshells. Clamshells were individually overwrapped with a micro-perforated 1-mil polyethylene film. The marketable shelf-life, percent rotted fruit, headspace atmosphere, postharvest quality, and sensory analysis were determined during 14-21 days storage at $40^{\circ} \mathrm{F}$.

The combination of ethanol (495.5 ppm), methyl jasmonate (4.5 ppm), citral (30 $\mathrm{ppm})$, linalool (30 ppm), and vanillin (30 ppm) was the most effective formula to reduce rot and increase shelf-life overall and strawberries treated with $600 \mathrm{ppm}$ of this blend had acceptable organoleptic quality. Applying high levels (750 ppm or more) of this formulation resulted in phytotoxic calyx desiccation after only 3 days at $40^{\circ} \mathrm{F}$. However, moderate amounts (300-600 ppm per package) did not desiccate the calyx until 7-11 days of storage which would allow sufficient time to market and consume the berries before the effect would be noticeable. A blend of essential-oil volatile compounds has the ability to reduce postharvest losses from B. cinerea, can be applied without spraying on or washing fruit.

Additional Index Words: Methyl jasmonate, carvacrol, thymol, citral, linalool, vanillin, Induced Acquired Resistance. 


\section{ACKNOWLEDGMENTS}

First, I would like to thank my graduate committee, Dr. J. Wyatt Brown, Dr. Lauren Garner, and Dr. Jennifer Carroll. I would also like to thank Tom Am Rhein and Naturipe Berry Growers for their support in the project. I would like to thank Jim Green for all of his help and training in lab.

Dr. Brown, I would personally like to thank you for all that you have done for me and this project over the course of the last few years. Working with you has significantly improved my skills as a writer, student, and researcher. I have the utmost respect for you as an educator and for your research. I hope that this thesis lives up to the high standards that you live and work by.

Dr. Garner, I would also like to thank you for your participation and support on this study. I am grateful for all that I was able to learn from you over the course of my higher education. Your intelligence, enthusiasm, and expertise in horticultural science is a blessing to all of the students fortunate enough work with you.

I would also like to express my gratitude to Dr. Carroll for her willingness to be on my committee, and for all the knowledge of chemistry she has shared with me for the last few years, especially for your expertise in plant essential-oils.

And last but certainly not least I would like to express my deepest gratitude to my family and friends, especially my grandparents, parents, and brothers. They have always been there for support, without which I could not have achieved all that I have so far. I love you all so very much. 


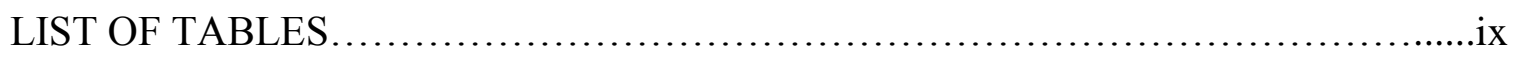

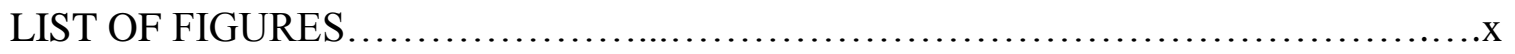

\section{CHAPTER}

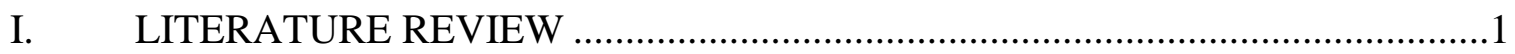

The Cultivated Strawberry ............................................................

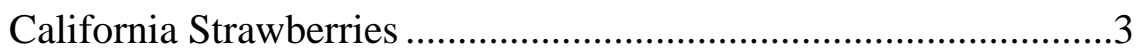

Development of the California Cultivars ...........................................

Summer and Winter Planting Systems …………………………....

Postharvest Handling of Strawberries...............................................6

Botrytis and Strawberries ...........................................................

Mechanisms of Botrytis Infection .................................................10

Botrytis cinerea in the Postharvest Environment............................12

Plant Essential-Oils with Fungicidal Activity.................................13

Methyl Jasmonate …………………………………………..... 14

Methyl Jasmonate and Botrytis................................................ 16

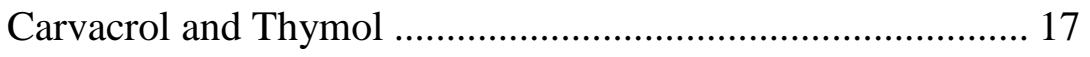

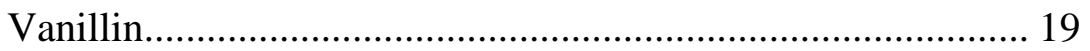

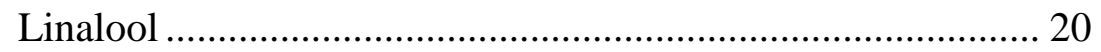


Conclusions......

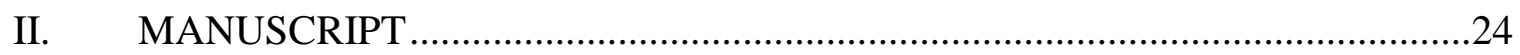

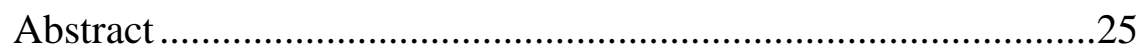

Introduction...............................................................26

Materials and Methods........................................................28

Microbial Studies .......................................................... 29

Brix and Titratable Acidity ............................................... 30

Weight Loss During Storage ............................................. 31

Experimental Design ..................................................... 31

Sensory Analysis ....................................................... 31

Gas Chromatograph (GC) Analysis ................................... 32

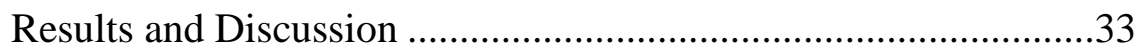

2012 Inoculation Studies............................................... 35

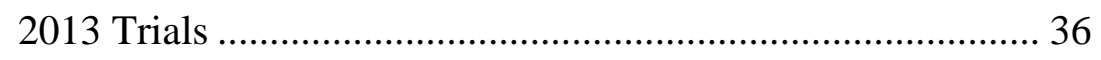

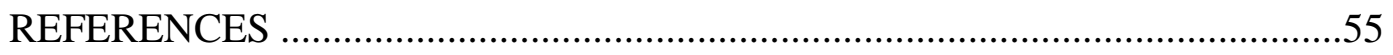




\section{LIST OF TABLES}

Table

Page

1. Effect of volatile compounds on the incidence of Botrytis cinerea

of strawberries indicated by percent rot and days shelf-life, 2011.

2. Days of shelf-life and \% rot of un-inoculated strawberries after

14 days at $4.4^{\circ} \mathrm{C}$ : November 7 to December $15,2011$.

3. Days of shelf-life and percent rot of strawberries 14 days after

inoculation with Botrytis cinerea. Berries were held at $4.4^{\circ} \mathrm{C}$. 45

4. Days of shelf-life, percent rot after 21 days at $4.4^{\circ} \mathrm{C}$, soluble solids, and total titratable acidity of un-inoculated strawberries.

5. Effect of mixing plant essential oils on their volatility compared to the pure standards.

6. Sensory analysis results for hedonic test conducted on July 10, 2013.

7. Individual overwrapped 454g clamshell packages: volatile compounds and treatment levels, 2011-2013. 


\section{LIST OF FIGURES}

FIGURE

Page

1. Chemical structure of methyl jasmonate. ................................................... 14

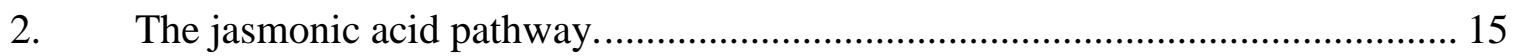

3. Chemical structures of the isomers carvacrol and thymol

(Hajimehdipoor et al., 2010)..................................................................... 18

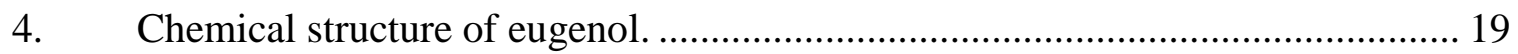

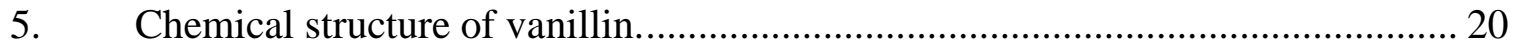

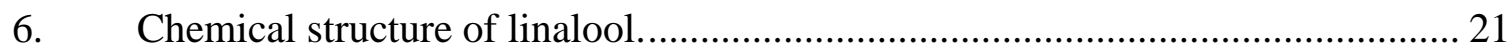

7. Chemical structure of citral. The geranial isomer to the left

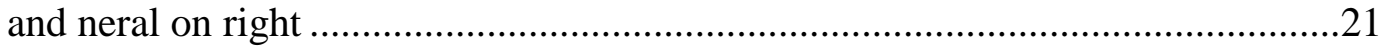

8. The phytotoxic effect of volatile treatments on strawberry calyxes exposed to ethanol and the essential-oil compounds carvacrol, thymol, and eugenol for 14 days at $4.4{ }^{\circ} \mathrm{C}$.

9. The phytotoxic effect of high levels (200 ppm) of citral and linalool on strawberry fruit after 14 days of exposure.... 46

10. Untreated fruit after 21 days of storage at $4.4^{\circ} \mathrm{C}$ showing excessive rot due to Botrytis cinerea.

11. Fruit treated with $590 \mathrm{ppm}$ of EtOH, vanillin, citral, linalool and methyl jasmonate 21 days after treatment at $4.4{ }^{\circ} \mathrm{C}$.

12. Ethanol effects on strawberry headspace oxygen levels immediately after treatment. Headspace oxygen $(r=0.80)$ and carbon dioxide of overwrapped strawberry packages treated with 0-1200 ppm of EtOH in $50 \mathrm{ppm}$ increments.

13. Regression analysis of the percent rotten fruit $(r=0.89)$, rot severity $(r=0.91)$, days shelf-life $(r=0.80)$, and days until calyx dried $(r=0.92)$ of fruit inoculated with Botrytis cinerea. Fruit were treated with $0-1200 \mathrm{ppm}$ of a $79.95 \% \mathrm{v} / \mathrm{v} \mathrm{EtOH}, 10 \% \mathrm{v} / \mathrm{v}$ vanillin, $5 \% \mathrm{v} / \mathrm{v}$ citral, $5 \% \mathrm{v} / \mathrm{v}$ linalool, and $0.05 \% \mathrm{v} / \mathrm{v}$ methyl jasmonate blend. Trial ended 17 days after inoculation. 


\section{CHAPTER I}

\section{LITERATURE REVIEW}

The strawberry (Fragaria x ananassa Duch.) is a member of Rosaceae, the rose family, and bears fruits known as achenes. The fruit are very tender and postharvest shrinkage of strawberries due to pathological disorders represents a significant portion of yearly losses (Mitcham et al., 1996). The incidence of Botrytis cinerea or grey mold, has been linked to both favorable disease conditions in the field and strawberry bloom senescence, causing losses of up to 30\% in the worst seasons (Paulus et al., 1969).

Since strawberry fruits are fragile and extremely perishable, timely harvest, cooling, and marketing of the fruits is a necessity. Chemical postharvest treatments to reduce losses have had limited application due to the reluctance to spray or wash the fruit. Volatile essential-oil compounds can be applied without a direct spray or dip application to fruit and offer the potential of an active treatment to reduce postharvest rot without significant changes to harvest practices.

\section{The Cultivated Strawberry}

The modern cultivated strawberry (Fragaria x ananassa Duch.) is a hybrid of two American species Fragaria chiloensis and Fragaria virginiana. Fragaria x ananassa, known as the pineapple strawberry, was first recognized as a hybrid species by Antoine Nicolas Duchesne of France in 1766 (Darrow, 1966). Duchesne credited the first cultivated pineapple strawberry hybrids to growers in the Netherlands though similar hybrids existed in the gardens of France, Germany, and England (Darrow, 1966). 
The Chilean strawberry, with its extremely large berries, was brought to France from Chile in 1714 by a French spy working for King Louis XIV (Darrow, 1966). This is considered one of the most important events in the history of the modern strawberry as these mother plants eventually resulted in a hybrid with $F$. virginiana. Chilean plants had also been transported to Europe from the New World by other travelers; however, only female plants had been selected from this dioecious species, resulting in extremely poor or no yields unless the plants happened to be near the compatible species Fragaria moschata or Fragaria virginiana (Darrow, 1966).

On July 6, 1764, Antoine Duchesne presented King Louis XV with a basket of extraordinarily large, beautiful, and delicious strawberry fruit grown from Fragaria chiloensis (Darrow, 1966). This fruit was very rare at the time in Europe. Duchesne had used pollen from the musky strawberry, $F$. moschata, to successfully pollinate the Chilean strawberry. The king graciously responded to this deed by commissioning Duchesne to grow more Chilean strawberries in the royal kitchen garden at Versailles and to collect all known Fragaria species grown or growing in Europe for preservation in the Trianon garden. Duchesne was only 17 at the time.

Two years after gifting the fruit to the king, Duchesne's research and experimentation resulted in the publication of the most scholarly and complete treatise ever written about the natural history of the strawberry, L'Histoire Naturelle des Fraisers (Duchesne, 1766). This is the work in which he identified the parentage of the pineapple strawberry. The suspected cross has subsequently been confirmed through genetic analysis (Darrow, 1966). 


\section{Duchesne wrote of Fragaria ananassa:}

"I suspect it to be a cross of the Scarlet strawberry ( $F$. virginiana) and the Fruitillar (Chilean). The flowers stems, branches and pedicels of $F$. ananassa resemble those of $F$. virginiana though due to their vigor they are larger than those of $F$. virginiana by half. The flowers almost equal $F$. chiloensis in size, but are more regular, with six petals and a similarly reflexed calyx. The fruit has no resemblance to $F$. virginiana but has a pale red color with a brown and yellowish cast, with very watery but solid flesh like that of the musky strawberry and the Chilean. In its center is a rather large cavity within which is a large, long central core which adheres to the calyx when the fruit is picked.

The ovaries are almost as large as those of the Chilean and are spread quite wide apart over the surface. The flesh swells very little in their interspaces, however, and thus is compact. The perfume of the fruit is closely similar to that of the pineapple. Pyramidal in shape, the berries are only a little smaller than the Chilean in size. The leaves are larger than those of the Virginian with petioles nearly twice the length so that each leaflet goes in a different direction, although on a horizontal plane. The leaflets are more vigorous and thicker than the Virginian's, so that they have a rough leathery texture like the Chilean's. They lack the dense pubescence of the Chilean, having very little hair. The plants resemble the Chilean in its vigor and its runners are about as big and as long. In color the leaves are like the Virginian (Darrow, 1966)."

Duchesne's father was an architect who had inherited the position of superintendent of Louis XIV's buildings, including the Trianon garden (Darrow, 1966). In his free time, the young Duchesne would explore the royal gardens and follow around the friendly head botanist, Bernard de Jussieu. Bernard was second in a five generation de Jussieu dynasty that occupied this prestigious position in botanical science for nearly 150 years. This early training in botany and natural history enabled Duchesne to recognize that the poor yield of $F$. chiloensis grown in Europe was due to the lack of a compatible pollinator.

\section{California Strawberries}

California currently grows $90 \%$ of the fresh-market strawberry crop in the United States (CSC, 2013). The crop has evolved from a 1,500 acre specialty fruit in 1945 to a 40,000 acre multi-billion dollar industry in 2013 (CSC, 2013). Strawberry growers in 
California benefit from fertile soils and a mild Mediterranean climate. However, the great success of the strawberry industry in California is attributed to intensive breeding programs, and the development of improved planting systems and cultural practices (Voth and Bringhurst, 1990).

\section{Development of the California Cultivars}

The strawberry breeding programs of the University of California and Driscoll Strawberry Associates (DSA) have produced some of the world's highest-yielding cultivars producing fruit with the longest shelf-life (Johnson, 1990). All hybrids produced in these programs are suspected to have at least one ancestor derived from the work of Albert Etter, 1872-1950 (Johnson, 1990). Etter was an early innovator in strawberry breeding, crossing a large fruited $F$. chiloensis from Peru to a $F$. chiloensis California beach strawberry he personally collected from Cape Mendocino (Darrow, 1966). Etter sought to improve the vigor, cold and drought tolerance, and selffruitfulness, of this large-fruited species through successive backcrossing to the wildtype. Etter's work resulted in many successful cultivars, some of which are still grown in England and New Zealand today (Johnson, 1990). Etter's most important contribution was to help lay the foundation for our current, highly-successful strawberry breeding programs.

Everbearing and day-neutral strawberries also originated in France, and are currently grown on a majority of the acreage in California (Johnson, 1990). Madame Elisa L. de Vilmorin, a devoted experimental botanist and artist is credited with naming a new strawberry species, Fragaria lucida, a highly vigorous plant with beautiful shiny leaves. 
Elisa received the specimen from a French agent who collected it along the California coastline during the gold rush era (Johnson, 1990). F. lucida was later proven to be $F$. chiloensis from California that was described as being bifere, or bearing two crops within a season by Ferdinand Gloede (Gloede, 1858). Gloede was the first to introduce an everbearing California-based $F$. ananassa hybrid named 'Ananas Perpertual' (Johnson, 1990).

\section{Summer and Winter Planting Systems}

Strawberries are currently grown as an annual crop though they were historically grown as a perennial crop (Voth and Bringhurst, 1990). Nursery plants were dug in the early springtime, grown on raised beds, and harvested for 3-4 years in Southern California and 4-8 years in Northern California. The development of summer and winter plantings enabled California growers to use annual planting systems (Voth and Bringhurst, 1990). Strawberries plants grown using annual systems produce consistently high yields of large, high quality fruit that ship and store well.

The summer planting system was first introduced to growers in 1955 (Voth, 1955). Plants were dug from nurseries in the Central Valley of California in December or January, when the plants were as near to dormant as possible with maximum starch content in the roots (Bringhurst et al., 1960). Leaves and petioles were removed and plants were stored below freezing $\left(-2.2^{\circ} \mathrm{C}\right)$ until planted on approximately September 1 . These "frigo" plants produced first-year-fruiting plants with larger, firmer, berries with a higher dessert quality and longer shelf-life compared to spring planted crops (Voth, 1955; Voth and Bringhurst, 1958). 
Summer plantings mostly disappeared after the development, in the late 1950s, of the winter planting system (Voth and Bringhurst, 1958; Bringhurst, 1960). Winter planting stock comes from high-elevation, high-latitude nurseries to ensure early chilling (Voth and Bringhurst, 1990). Additional cold chamber chilling at $1-2^{\circ} \mathrm{C}$ is given for $0-4$ weeks depending on cultivar. Winter planting enables growers to harvest fruit within 3-4 months instead of the 7 months required with summer plantings. Most acreage is replanted each year in order to produce the highest quality, largest fruit.

\section{Postharvest Handling of Strawberries}

Strawberries are an extremely perishable fruit. Strawberries are place-packed into polyethylene terephthalate (PET or PETE) clamshells in the field then rushed to forcedair coolers where they are cooled to $1^{\circ} \mathrm{C}$. Clamshells with $30 \%$ vent area reduced $7 / 8$ 's cooling time of strawberries down to 67 minutes (Thompson and Knutson, 1997).

Strawberries are shipped at $1^{\circ} \mathrm{C}$, and most strawberries are shipped using the Tectrol ${ }^{\odot}$ system which employs a 3-mil polyethylene pallet overwrap to trap a $13 \% \mathrm{CO}_{2}$-enriched modified atmosphere (MA) around the berries (Transfresh, 2012). The Tectrol system costs growers/shippers approximately $\$ 0.28$ per flat of strawberries. Other pallet overwrap systems such as Peakfresh bags (PeakfreshUSA, 2013) and $\mathrm{CO}_{2}\left(\mathrm{CO}_{2}\right.$ Technologies, 2013) emitting pads are used but on a much smaller scale.

Postharvest rot is significant as losses not only involve the fruit, but also the costs of harvesting, packaging, cooling, and transportation. Additionally, markets may become depressed due to consumer dissatisfaction (Paulus, 1990). The two most common postharvest pathogens of strawberry are Botrytis cinerea and Rhizopus stolonifer 
(Mitcham et al., 1996). Botrytis cinerea or grey mold is the most costly and damaging postharvest disease (Mitcham et al., 1996). Though a significant pathogen, $R$. stolonifer, cannot germinate below $5{ }^{\circ} \mathrm{C}$ (Dennis and Cohen, 1976) and is controlled by storage and shipment at $1{ }^{\circ} \mathrm{C}$.

\section{$\underline{\text { Botrytis and Strawberries }}$}

Botrytis cinerea is ubiquitous in the environment and has proven difficult to manage due to its wide host range and the development of fungicide-resistant populations (Dennis and Cohen, 1976; Mercier et al., 2010). It is a necrotrophic pathogen in Sclerotinaceae and is both a saprophyte and parasite of plants (Smith, 1902), which may be the primary reason it is so difficult to control.

Botrytis cinerea infection occurs throughout the growing season in strawberry fields as it may be present as a facultative parasite and saprophyte on a wide variety of plant materials (Jarvis, 1962b). The majority of new infections are thought to be initiated from mycelia that are growing saprophytically in plant tissues adjacent to the infection sites. The primary source of inoculum within a strawberry field is considered to be the dead leaves that remain attached to the strawberry plants (Braun and Sutton, 1987). Botrytis

cinerea mycelia have also been observed in the senescent petals, stamens, and calyces of marketable strawberry fruit (Powelson, 1960). Postharvest rot was reduced when petals, stamens and calyces were removed after fertilization (Powelson, 1960).

Stamens are considered a more important source of latent fruit infections than either the stigma or style (Bristow et al., 1986). The stigma and style became infected after inoculation; however, it took 4-6 weeks for the mycelial growth to reach the style from 
the stigma and, then, growth appeared to be inhibited. Mycelia were observed to grow from the stamen through the filament and into the proximal end of the strawberry receptacle. These observations suggest it is unlikely that the mycelia would grow onward into the carpel from the style and is more likely to arise from infections of the stamen.

Botrytis cinerea produces both sclerotia and conidia. Sclerotia are the primary survival/overwintering bodies of $B$. cinerea and are viable over the large temperature range of $4-54{ }^{\circ} \mathrm{C}$ (Badaboost, 2000). The sclerotia usually produce conidia but can also infect via hyphae. Sclerotia will occasionally produce an apothecium (fruiting body) and the resulting ascospores can also infect strawberry plants. Hyphae and germinated conidia both give rise to conidiophores.

Conidia are the primary inoculum dispersed by B. cinerea in strawberry fields (Holz et al., 2004). Ninety to $99 \%$ of conidia were found to be produced from mycelium in the laminae and petioles of senescing strawberry leaves (Braun and Sutton, 1987). Spores of Botrytis cinerea are dispersed from conidiophores by both air currents and splashing rain. Maximum airborne conidial concentration was observed at $65-85 \%$ relative humidity; however, at times of rainfall, spore dispersal also occurred (Jarvis, 1962a). Spore counts up to $10^{4}$ per $\mathrm{m}^{3}$ of air have been observed.

Optimal conditions for B. cinerea conidial germination are $15-25{ }^{\circ} \mathrm{C}$ (Badaboost, 2000) and, for infection of strawberry tissues, $15-20{ }^{\circ} \mathrm{C}$ (Devaux, 1978). Infection of tissues usually occurs within $5 \mathrm{hr}$ of spore germination. Infection rarely occurs at temperatures above $25^{\circ} \mathrm{C}$ (Badaboost, 2000). Botrytis cinerea conidia do not germinate easily in a simple, saturated atmosphere (Jarvis, 1962b). The conidia require a water potential $(\mathrm{A} w)$ of at least 0.93 to germinate and thrive (Rousseau and Doneche, 2001). 
Humidity levels of 93\% and 95-100\% resulted in 2-day and 1-day germination periods, respectively, for B. cinerea conidia (Snow, 1949). One-hundred percent of inoculated strawberry flowers were infected after $24 \mathrm{hr}$ of $100 \%$ humidity at $20{ }^{\circ} \mathrm{C}$ (Bulger et al., 1987).

Glucose and fructose enhance $B$. cinerea conidial germination and growth (Blakeman, 1975; Cole et al., 1996 ; Doehleman et al., 2005). When conidia were germinated in vitro, fructose was observed to stimulate germination while sucrose did not (Blakeman, 1975). Inorganic nitrogen sources were also observed to stimulate germination and growth but only when combined with glucose. Sugar and nutrients may be supplied to plant pathogens via exosmosis that results from free water on plant surfaces (Browne, 1915).

The mycelia of $B$. cinerea were able to survive for up to twelve months at $95-100 \%$ humidity in the absence of nutrients (Van Den Berg et al., 1968). Humidity levels below $95 \%$ resulted in a survival time of approximately one month. In the presence of nutrients, mycelial growth occurred at $\geq 93 \%$ humidity and the maximum growth rate occurred at $20{ }^{\circ} \mathrm{C}$. No mycelial growth was observed with added nutrients when humidity was less than $93 \%$, and survival time of the mycelia was approximately one month.

A clear indication of the potential reduction of $B$. cinerea due to unfavorable conditions was observed in a study comparing high-tunnel-grown vs. field-grown strawberries (Xiao et al., 2001). Fruit from the untreated check (UTC) in the tunnel had a rot incidence of only $2 \%$ while fruit from the field-grown UTC plants had a rot incidence of $89 \%$. The researchers postulated that the reduction was due to the higher temperatures in the tunnels and shortened time dew persisted on plants each day. 


\section{Mechanisms of Botrytis Infection}

Botrytis cinerea infects with a diverse blend of enzymes, toxins and active oxygen species, and by using mechanical force (Choquer et al., 2007). It produces cell-walldegrading enzymes like cutinase and pectinase, toxins like botyrdial, and low molecular weight compounds such as oxalic acid (Williamson et al., 2007). The various compounds utilized are diverse and have differing importance and roles in pathogenesis, tissue degradation and secondary infection. Though many different factors have been studied, the exact mechanism used by $B$. cinerea to infect is not completely understood.

Infection by $B$. cinerea can be divided into three main steps: surface and nutrient sensing, penetration of the host surface, and sporulation (Van Kan, 2006). Initially, there is conidial attachment to a susceptible host followed by conidial germination and development of the appressorium, or penetration structure. Following successful penetration, the host tissue is killed with lytic enzymes, resulting in tissue maceration and lesion expansion. During sporulation, conidiophores are produced that ultimately lead to secondary infections.

Germlings of $B$. cinerea do not use sheer mechanical force via the appressorium to invade plant cells as do some phytopathogens. A distinct amorphous extracellular matrix has been observed, via electron microscopy, on germ tubes at the site of penetration (Cole et al., 1996). The extracellular matrix was found to contain $20 \%$ carbohydrates, $28 \%$ protein, 6\% lipids and 46\% melanin (Doss, 1999; Doss et al., 2003). Enzymatic content of the matrix was determined and it was found to contain polygalacturonase, laccase, cutinase, cellulase, pectin lyase, and pectin methyl esterase. These enzymes degrade the host's tissue defenses, enabling Botrytis to enter the host without using tremendous force. 
Botrytis cinerea produces a range of endopolygalacturonases, expressed in genes Bcpg1-6. These genes were found to be differentially expressed depending on the stage of infection and tissue type (Ten Have et al., 2001). Other researchers found that partial gene replacement of gene Bcpg-1 had no effect on initial infection but resulted in significant reductions in secondary infections, indicating that this gene is required for full virulence (Have et al., 1998).

Similar studies have indicated that deletion of the cutA gene, coding for cutinase, did not reduce the ability of germinating $B$. cinerea conidia to penetrate host tissues (Van Kan et al., 1997). Cutinase is present in normal conidia from germination onward. This suggests that a combined mechanism of multiple enzymes and other factors are likely used for initial infection.

The hypersensitive response (HR) of plants is a programmed series of events that results in cell death and an oxidative burst of reactive oxygen intermediates (ROIs) that are mostly hydrogen peroxide molecules (Govrin and Levin, 2000). The HR evolved as an effective defense against biotrophic pathogens. Botrytis cinerea, a facultative necrotroph, has been found to capitalize on the HR of plants and may do so alone or as part of a disease complex that results in massive decay (Govrin and Levin, 2000). Hydrogen peroxide levels in plant tissues were found to be positively correlated with the growth of B. cinerea. When Arabidopsis thaliana mutants lacking the HR-gene were infected with $B$. cinerea, growth of this fungus was significantly reduced.

Botrytis cinerea produces the toxin botrydial within the soft rot regions of infections (Deighton et al., 2001). However, botrydial concentration was not positively correlated with pathogenicity and resulted in relatively low host susceptibility when isolated and 
applied to healthy plant tissues. Results indicated that botrydial may be simply one factor of pathogenesis, not a key determinant.

\section{Botrytis cinerea in the Postharvest Environment}

Botrytis cinerea is a versatile pathogen infecting numerous plant parts and tissues, especially those that are senescing. It is considered the most important postharvest pathogen worldwide affecting more than 200 crops (Droby and Lichter, 2007, Williamson et al., 2007), and postharvest losses can reach up to 50\% in developing countries that lack refrigeration (Droby and Lichter, 2007). Unlike many fungi, Botrytis cinerea is able to grow slowly at temperatures as low as $0.25^{\circ} \mathrm{C}$ (Dennis and Cohen, 1976).

Botrytis cinerea was completely inhibited in vitro at $1{ }^{\circ} \mathrm{C}$ when kept in an atmosphere of 25-30\% $\mathrm{CO}_{2}$ (Agar et al., 1990). Plates kept at temperatures between 10$20^{\circ} \mathrm{C}$ required $>40 \% \mathrm{CO}_{2}$ for complete inhibition of growth. Reducing $\mathrm{O}_{2}$ levels from $21 \%$ to $1 \%$ had no effect; however, growth was partially inhibited at $0.2 \% \mathrm{O}_{2}$ and completely inhibited with no $\mathrm{O}_{2}$ present. Reducing $\mathrm{O}_{2}$ to $1 \%$ coupled with $20 \% \mathrm{CO}_{2}$ resulted in no additional inhibitory effect.

It is obvious that the in vitro response of $B$. cinerea to high levels of $\mathrm{CO}_{2}$ and low levels of $\mathrm{O}_{2}$ is atypical as modified atmosphere (MA) technology is currently used in the strawberry industry to reduce $B$. cinerea growth (El-Kazzaz et al., 1983; Browne et al., 1984). Carbon dioxide is injected into sealed, low-density-polyethylene pallet overwrap bags (Artes et al., 2001). Strawberries in an atmosphere containing $15 \% \mathrm{CO}_{2}$ or a controlled atmosphere (CA) of 2-4\% $\mathrm{O}_{2}$ and $10 \% \mathrm{CO}_{2}$ effectively reduced rot from $B$. 
cinerea and extended shelf-life up to 21 days (El-Kazzaz et al., 1983). However, tissue discoloration and off-flavors were observed with the $15 \% \mathrm{CO}_{2}$ treatment. Oxygen levels reduced to 0.25 or $0 \%$ have also reduced decay but off-flavors developed in the fruit, likely from anaerobiosis (Ke et al., 2006).

Strawberry clamshells overwrapped in perforated, polypropylene film developed $\mathrm{CO}_{2}$ levels sufficient to reduce fruit rot (Sanz et al., 2006). However, there were adverse effects on color and off-flavors developed in the berries. Strawberry fruit quality was also reported to be poor after storage in polyethylene bags in which $\mathrm{CO}_{2}$ levels were allowed to rise gradually to fungistatic levels (Larsen and Watkins, 1995). In contrast, the rapid infusion of a $10 \% \mathrm{CO}_{2}: 2 \% \mathrm{O}_{2}$ mixture reduced rot, delayed ripening and resulted in firmer berries (Larsen and Watkins, 1995). There was no off-flavor development when compared to the untreated check. A $20 \% \mathrm{CO}_{2}$ treatment also reduced rot but resulted in off-flavors after only 3 days of storage. The off-flavors subsequently decreased when strawberries were held for $24 \mathrm{hr}$ at $20^{\circ} \mathrm{C}$.

The reduction of both decay and quality of fruit in MA storage may depend on fruit ripeness level (Nunes et al., 2002). Fruit at 3/4 ripeness maintained better appearance, firmness and quality compared to fully ripe fruit, when held at 4 or $10{ }^{\circ} \mathrm{C}$ with $5 \% \mathrm{O}_{2}$ and $15 \% \mathrm{CO}_{2}$. Nearly ripe (3/4 ripe) fruit were mostly free of decay and maintained soluble solids and acidity after two weeks of storage.

\section{Plant Essential-Oils with Fungicidal Activity}

Plant essential oils have been known for millennia for their preservative effects. The first recorded attempt at using a plant extract for the preservation of food was by 
Democritus in 600 B.C. (Arya and Perello, 2010). Recently there has been a resurgence of interest in using plant extracts as natural anti-microbial treatments for the preservation of food (Burt, 2004; Serrano et al., 2008; Tripathi and Dubey, 2003). Plant essential oils have the potential to reduce postharvest rots and many are food-safe compounds (FDA, 2012).

\section{Methyl Jasmonate}

Methyl jasmonate (Fig. 1), the volatile methyl ester of jasmonic acid, was first identified in 1962 from essential oils of the jasmine plant, Jasminum grandiflorum (Demole et al., 1962). Jasmonic acid and methyl jasmonate are members of a recently

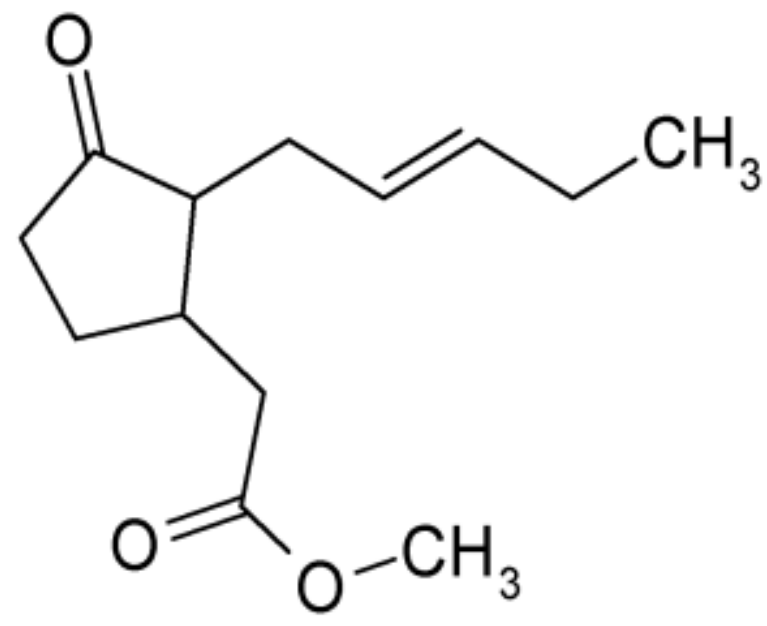

Fig. 1. Chemical structure of methyl jasmonate.

discovered group of plant hormones called jasmonates. Jasmonic acid and methyl jasmonate are found in many higher plants and are produced via the jasmonic acid pathway (Creelman and Mullet, 1997). This pathway begins with the breakdown of linolenic acid and ends with the production of jasmonic acid (Fig. 2). 


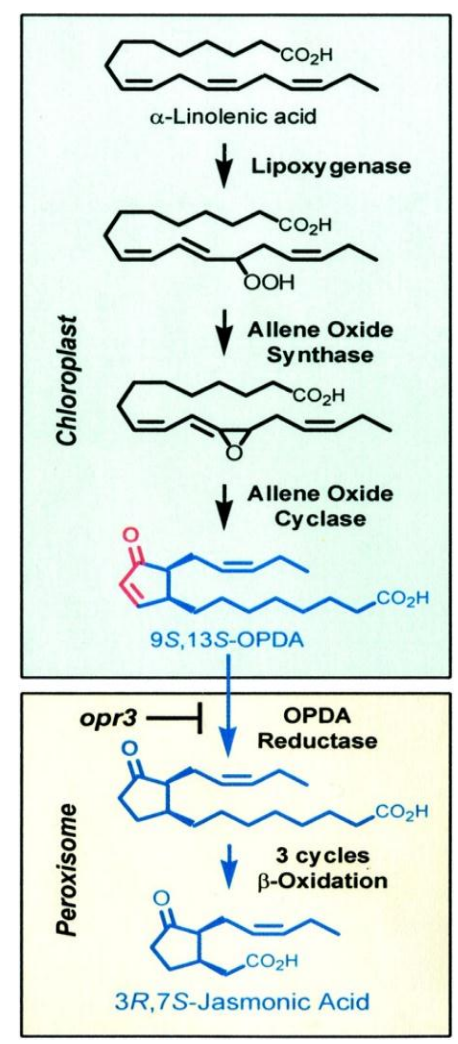

Fig. 2. The jasmonic acid pathway.

Methyl jasmonate exposure may result in induced systemic resistance (ISR) in plant tissues (Piertense et al., 1996). Unlike systemic acquired resistance (SAR), ISR is not related to the accumulation of pathogenesis proteins or salicylic acid, but relies on pathways regulated by jasmonate and ethylene (Vallad and Goodman, 2004). Methyl jasmonate is involved in interplant communication in a similar manner to ethylene and has also been found to be produced in response to herbivory (Thaler, 1999).

The pathways for systemic acquired resistance and induced systemic resistance can be antagonistic or synergistic depending on the invading pathogen and conditions experienced by the plant (Kunkel and Brooks, 2002). The production of jasmonates is a plant's response to attack by necrotrophic fungi such as B. cinerea and others (Vallad and Goodman, 2004). 


\section{Methyl Jasmonate and Botrytis}

Methyl jasmonate at a rate of $10^{-5} \mathrm{mM} / \mathrm{L}^{-1}$ controlled Botrytis rot on strawberries for two weeks when it was wick applied for $24 \mathrm{~h}$ to berries held in a sealed container at 20 ${ }^{\circ} \mathrm{C}$ (Moline et al., 1997). Research at the USDA has indicated similar results and the estimated cost of treating strawberries with methyl jasmonate was $\$ 30$ per truck load (Stanley, 1998).

Methyl jasmonate exposure was subjectively observed to increase strawberry scent (Moline et al., 1997) and has subsequently been shown to also increase antioxidant compounds such as resveratrol (Wang et al., 2007) while increasing strawberry flavor volatiles (methyl and ethyl esters) (Ayala-Zavala et al., 2005). No significant increases were observed in flavonols after strawberries were exposed to methyl jasmonate (de la Pena-Moreno et al., 2010b). Application of methyl jasmonate to postharvest strawberries resulted in the formation of phytoalexins: $\mathrm{B}_{1,3}$-gluconase, polyphenol oxidase, and chitinase (Zhang et al., 2006). Methyl jasmonate has also been shown to increase the postharvest shelf-life of raspberries (Wang et al., 2005) and the shelf-life and concentration of flavor volatiles in blackberries (Blanch et al., 2011).

Methyl jasmonate has different effects on strawberries during specific growth periods (Gassner et al., 1997) and there may be other undiscovered applications for this compound. Application of $0.5 \mathrm{mM}$ jasmonic acid was found to decrease strawberry pollen tube germination from 42.5 down to $5.8 \%$ compared to untreated controls (Yildiz et al., 2002). However, methyl jasmonate may increase the rate of strawberry ripening due to its promotion of ethylene biosynthesis (Mukkun, 2009). The effects of methyl jasmonate must be further evaluated in relation to plant maturity, and plant maturity may 
be the ultimate factor used when deciding if and when to apply jasmonates in the field. At present, the most promising use of methyl jasmonate appears to be as a postharvest treatment of strawberries.

\section{Carvacrol and Thymol}

Carvacrol is also known as cymophenol $\left(\mathrm{C}_{6} \mathrm{H}_{3} \mathrm{CH}_{3}(\mathrm{OH})\left(\mathrm{C}_{3} \mathrm{H}_{7}\right)\right)$ and is a monoterpenoid phenol. It is produced in a variety of plants with the highest levels (60$85 \%$ ) reported in varieties of Originum vulgare (Novak et al., 2002). Carvacrol is one of the most well-known natural antibiotics and has been tested both in-vitro and in-vivo (Burt and Reinders, 2003; Milos et al., 2000). The antimicrobial activity of carvacrol is likely related to its chemical structure (Fig. 3). The specific level of hydrophobicity of carvacrol allows it to adhere to the cell wall of pathogens like grey mold and accumulate to fungicidal levels. The delocalized system of proton sharing within the phenolic ring allows for proton exchange from the free hydroxyl group, and results in membrane disruption (Ben Arfa et al., 2006).

Thymol is a monoterpene phenol also known as cymene or 2-isopropyl-5methylphenol, and has a molecular formula of $\mathrm{C}_{10} \mathrm{H}_{14} \mathrm{O}$. Thymol is an isomer of carvacrol, found in thyme oil, and usually extracted from common thyme (Thymus vulgaris). Thymol is also found in other plants and occurs as a white crystalline substance with a pleasant aromatic odor and strong antiseptic properties (Lawless, 1995). Thymol has a distinctive, strong flavor. After two weeks on inoculated strawberries, extracts of thyme inhibited B. cinerea $75.8 \%$ compared to an untreated control (Bhaskara Reddy et al., 1998). 
In vitro, carvacrol at a concentration of $100 \mathrm{ppm}$ completely inhibited the growth of B. cinerea, and had a minimal inhibitory concentration (MIC) of 5 ppm (Ben Arfa et al., 2006). Incidence of Botrytis on table grapes was significantly reduced when carvacrol or thymol was used at a concentration of 200-1000 ppm (Serrano et al., 2008). Off-flavors in table grapes were reported after their treatment with carvacrol (Ben Arfa et al., 2006; Guillen et al., 2007). Carvacrol has also been incorporated into active packaging for lettuce but the lettuce developed off-flavors due to the carvacrol (Ben Arfa et al., 2007; Muriel-Galet et al., 2013).

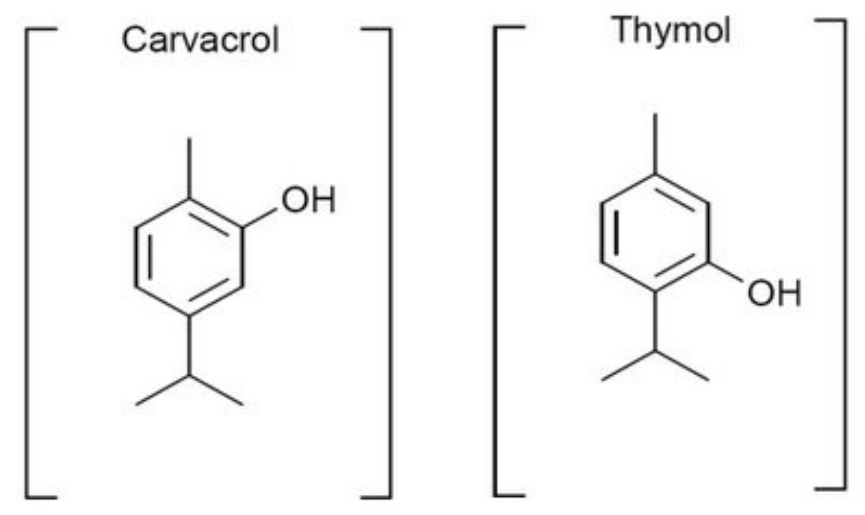

Fig. 3. Chemical structures of the isomers carvacrol and thymol (Hajimehdipoor et al., 2010).

Guillen et al., 2007 observed synergy when combining carvacrol, thymol and eugenol (Fig. 4) in formulations to control grey mold of table grapes. This formulation allowed the researchers to reduce overall treatment level to $75 \mathrm{ppm}$ from $200 \mathrm{ppm}$ required in previous in-vivo tests with pure carvacrol. When grapes were treated with this combination, 8 of 10 trained taste panelists could detect no noticeable off-flavors. 


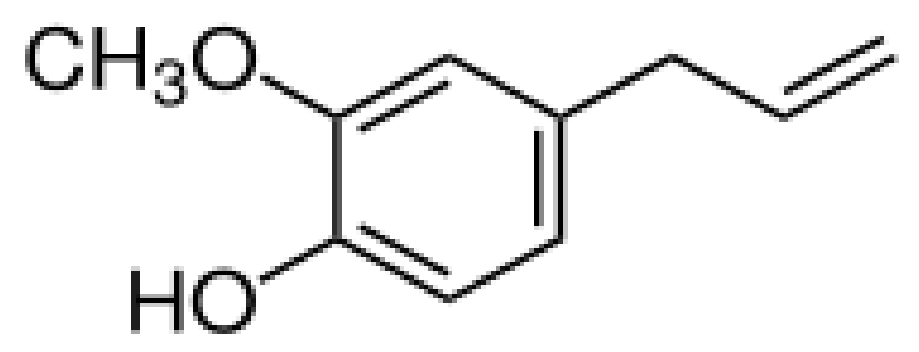

Fig. 4. Chemical structure of eugenol.

\section{Vanillin}

Vanillin is a phenolic aldehyde with the molecular formula $\mathrm{C}_{8} \mathrm{H}_{8} \mathrm{O}_{3}$ (Fig. 5). It is the primary flavor constituent in vanilla bean extract though it comprises only $\sim 2 \%$ of the total weight of extracted flavor compounds (Lawless, 1995). Annual demand for natural vanillin typically exceeds supply, so chemically-synthesized vanillin makes up the majority used in the food industries (Dignum et al., 2001).

A shelf-stable strawberry puree was made by incorporating $3000 \mathrm{ppm}$ vanillin into the mixture (Cerutti et al., 1997). The strawberry puree lasted 56 days at $68^{\circ} \mathrm{F}$ without rotting or having excessive yeast accumulation. Vanillin was found to have a synergistic effect in vitro on the inhibition of $B$. cinerea, when combined with either lavender or thyme extracts (Rattanapitigorn et al., 2006). Botrytis was completely inhibited for $72 \mathrm{hr}$ by both blends. 


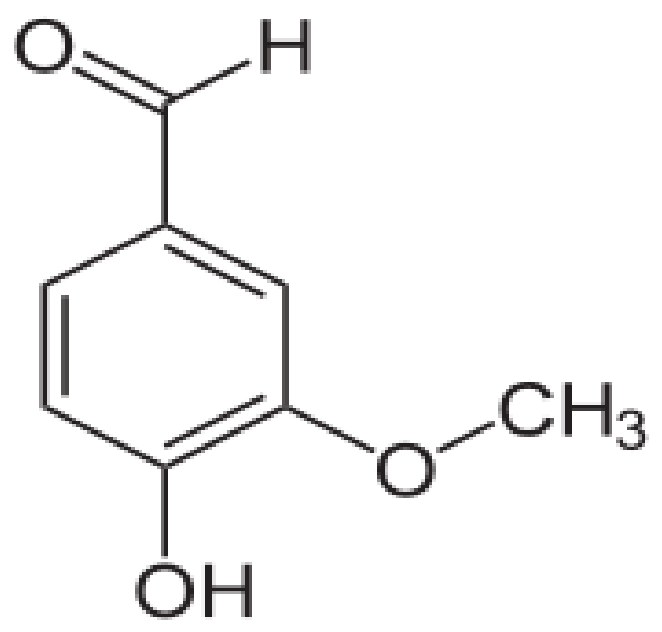

Fig. 5. Chemical structure of vanillin.

\section{Linalool}

Linalool is a naturally occurring terpene alcohol (Fig. 6) with the molecular formula $\mathrm{C}_{10} \mathrm{H}_{18} \mathrm{O}$. Linalool has a strong floral scent and is commonly used in soaps and other bath products (Lawless, 1995). It is the primary constituent of lavender essential-oil; however, it is found in numerous plant parts including citrus peels (Droby et al., 2008) and strawberry leaves and fruit.

Linalool extracted from citrus peels and applied to Petri dishes at $5 \mu \mathrm{L} /$ plate prevented germination of B. cinerea spores (Droby et al., 2008). Enantiomeric distribution of linalool within many plants indicated that (-)linalool is more common than (+)linalool (Özek et al., 2010). Both enantiomers resulted in a 50\% inhibition of $B$. cinerea after $48 \mathrm{hr}$, when the fungus was exposed to linalool at a concentration of 3 or 30 $\mu \mathrm{M}$. Linalool was second only to p-cymene, and was more efficacious than carvacrol, in controlling Botrytis rot on blueberries (Wang et al., 2008). 


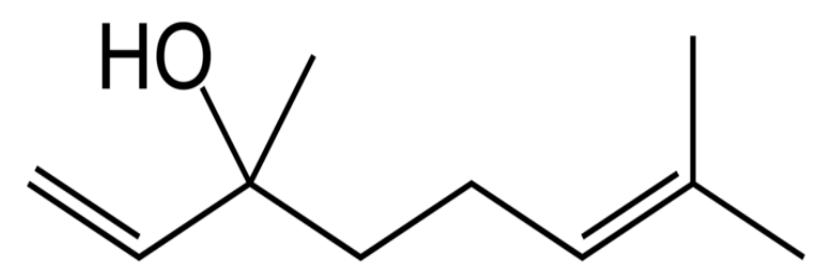

Fig. 6. Chemical structure of linalool.

\section{Citral}

Citral is known as 3,7-dimethyl-2,6-octadienal or lemonal and has the molecular formula $\mathrm{C}_{10} \mathrm{H}_{16} \mathrm{O}$ (Fig. 7). Citral is an aldehyde typically composed of two isomers: geranial or citral A, and neral or citral B; however, both can occur alone in plants. Citral is a yellow liquid with an extremely powerful lemon scent and is commonly used in the perfume and flavor industries (Lawless, 1995). Citral is found in many plants but is typically extracted from lemon grass (70-80\%) and the highest levels are found in lemon balm (90\%) (Lawless, 1995).
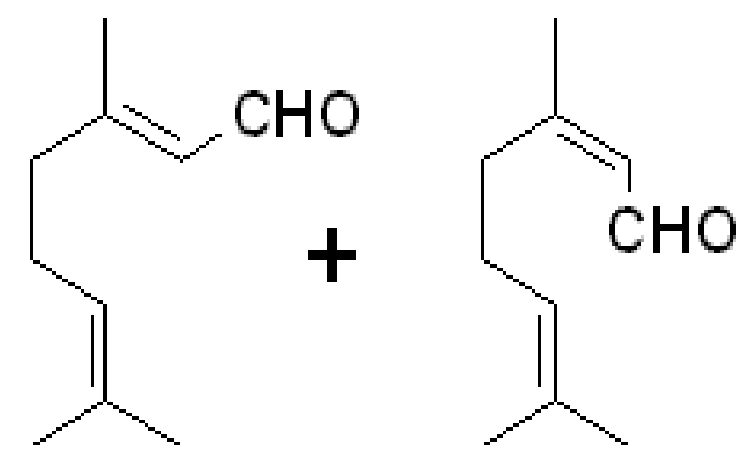

Fig. 7. Chemical structure of citral. The geranial isomer to the left and neral on right. 
Citral is known to be antimicrobial (Onawumni, 1989), and when $1 \mu \mathrm{l}$ was applied to fungal plates, it inhibited the germination and growth of $B$. cinerea spores (Droby et al., 2008). A similar study found that $250 \mathrm{ppm}$ citral completely inhibited the growth of $B$. cinerea (Camele et al., 2012). Anti-microbial film containing citral was more effective at controlling microbes on chopped lettuce than film containing oregano extract (MurielGalet et al., 2013). Incorporating citral in the film resulted in a $2.13 \log$ reduction of enterobacteria and a $2 \log$ reduction of yeast and molds.

\section{$\underline{\text { Conclusions }}$}

The marketing of fresh strawberries is a challenge due their relatively short shelf-life and disease susceptibility. Pathological disorders result in the greatest postharvest losses of strawberries and the two most common postharvest pathogens are $B$. cinerea and Rhizopus stolonifer. Botrytis cinerea, which causes grey mold of strawberry, results in the most severe postharvest losses because it is a ubiquitous, facultative necrotroph, and has ability to grow at temperatures as low as $0.25^{\circ} \mathrm{C}$. Modified atmosphere storage with elevated $\mathrm{CO}_{2}$ is the primary method used to control B. cinerea postharvest decay of strawberries; however, atmospheres containing $\geq 15 \% \mathrm{CO}_{2}$ may result in discoloration of the berries and off-flavor development.

Recent research with natural plant volatiles has indicated that they have both antifungal and anti-bacterial properties. Essential oil compounds that may reduce Botrytis incidence are: thymol from thyme, carvacrol from oregano, eugenol from clove, methyl jasmonate from jasmine, linalool and citral from citrus peels, and vanillin from vanilla bean. Ethanol treatment has also been reported to control Botrytis rot. 
Carvacrol, thymol, eugenol, citral, linalool, and vanillin are fungicidal whereas methyl jasmonate causes induced systemic resistance (ISR) within ripe strawberries. This results in the production of phytoalexins such as chitinase, increases free radical scavengers (ORACs) and flavor volatiles. Methyl jasmonate along with other volatile essential-oil compounds are food safe candidates for use in the postharvest management of grey mold on strawberries. 


\section{CHAPTER II}

\section{MANUSCRIPT}

\section{Novel Plant Essential-oil Treatments Reduce the Postharvest Incidence of Botrytis cinerea on Fresh Strawberries}

Ryan Brantley, J. Wyatt Brown ${ }^{1}$, and Amy Lammert ${ }^{2}$.

Horticulture and Crop Science Department ${ }^{1}$, and Food Science and Nutrition

Department $^{2}$, California Polytechnic University, San Luis Obispo, 1 Grand Ave, San Luis Obispo, CA 93401

Partial funding for this project was provided by the California State University Agricultural Research Institute (ARI). We also thank Naturipe Berry Growers for both strawberries and financial support of this research.

\footnotetext{
${ }^{1}$ To whom reprint requests should be addressed. Email: wbrown@calpoly.edu
} 


\title{
Subject category: Postharvest Biology
}

\section{Novel Plant Essential-oil Treatments Reduce the Postharvest Incidence of Botrytis cinerea on Fresh Strawberries}

\author{
Additional Index Words. Methyl jasmonate, carvacrol, thymol, citral, linalool, \\ vanillin, Induced Acquired Resistance.
}

\begin{abstract}
$\underline{\text { Abstract }}$
Plant essential-oil blends with fungicidal and resistance-inducing effects were added via sachet inserts to overwrapped strawberry (Fragaria x ananassa Duch, Cv. Albion) clamshells, to control postharvest grey mold, Botrytis cinerea. Combinations of methyl jasmonate, carvacrol, thymol, eugenol, vanillin, citral, cinnamaldehyde, or linalool were evaluated. The marketable shelf-life, percent rotted fruit, postharvest quality of the berries, and headspace atmosphere within the packages, were evaluated during 14-21 days of storage at $4.4^{\circ} \mathrm{C}$. Strawberries treated with methyl jasmonate and ethanol (3751200 ppm per package) together with blends of carvacrol, eugenol and thymol (5-375 ppm per sachet per package) or citral, linalool (5-250 ppm per sachet per package), and vanillin (30-60 ppm), significantly reduced rot and increased shelf-life compared to untreated fruit or fruit treated with ethanol or methyl jasmonate. Treatments containing citral and/or linalool were found to be phytotoxic to both the strawberry calyx and the fruit at the highest levels tested (250 ppm essential oil/package). Oxygen levels inside overwrapped clamshells were negatively correlated with ethanol rate immediately after
\end{abstract}


volatile application and throughout the storage period. The combination of ethanol (495.5 ppm), methyl jasmonate (4.5 ppm), citral (30 ppm), linalool (30 ppm), and vanillin (30 ppm) was the most effective formula to reduce rot and increase shelf-life overall and strawberries treated with 600 ppm of this blend maintained acceptable organoleptic quality.

\section{$\underline{\text { Introduction }}$}

Strawberries are enjoyed worldwide. Strawberry production in the U.S. was $\$ 2.2$ billion dollars in 2012 (USDA, 2013). California produces $90 \%$ of the fresh-market strawberry crop in the United States (CSC, 2013). The marketing of fresh strawberries is a challenge due to their high respiration rate (Kader, 1991), short shelf-life, and susceptibility to disease (Sommer et al., 1973).

Pathological disorders result in the greatest postharvest losses of strawberries and the two most common postharvest pathogens are B. cinerea and Rhizopus stolonifer (Maas, 1998; Wells, 1970). Botrytis cinerea, which causes grey mold of strawberry, results in the most severe postharvest losses because it is a ubiquitous, facultative necrotroph with the ability to grow at temperatures as low as $0{ }^{\circ} \mathrm{C}$ (Mitcham et al., 1996). In contrast, $R$. stolonifer cannot germinate below $5{ }^{\circ} \mathrm{C}$ (Dennis and Cohen, 1976) and is controlled by storage and shipment at $1{ }^{\circ} \mathrm{C}$.

Consumers are demanding produce that is free of pesticide residues (Tripathi and Dubey, 2003). Recent research with plant essential-oils has indicated they have anti- 
fungal properties. Essential oil compounds shown to reduce the incidence of Botrytis are: thymol from thyme (Abd-Alla et al., 2011; Bhaskara Reddy et al., 1998; Guillen et al., 2007), carvacrol from oregano (Ben Arfa et al., 2006; Guillen et al., 2007), eugenol from clove (Guillen et al., 2007), methyl jasmonate from jasmine (Moline et al., 1997), linalool and citral from citrus peels (Droby et al., 2007), and vanillin from vanilla bean (Rattanapititgorn et al., 2006). Ethanol (EtOH) treatments have also been reported to reduce Botrytis rot on organic strawberries (Karabulut et al., 2004).

Little research has been done to examine the use of essential-oils blends in a formulation that combines different modes of action but this has been recommended as a way to increase efficacy when using natural products to control decay (Guillen et al., 2007; Tripathi and Dubey, 2003). Methyl jasmonate causes Induced Systemic Resistance (ISR) in plants (Pierterse et al., 1996) whereas carvacrol, thymol, eugenol, citral, linalool, and vanillin are fungicidal. Applying methyl jasmonate to ripe strawberries results in the production of the phytoalexin chitinase (Zhang et al., 2006), increases free radical scavengers (ORACs) (Ayala-Zavala et al., 2005; Chanjirakul et al., 2007; Wang et al., 2007) and flavor volatiles (de la Peña Moreno et al., 2010a). No information is currently available regarding the use of plant-derived volatile compounds as a postharvest strawberry treatment to reduce grey mold on widely-grown strawberry cultivars.

The goal of this research was to develop a formulation of essential oil compounds to control 95\% of strawberry Botrytis rot without compromising postharvest fruit quality. Primary objectives were to investigate the use of phytoalexin-inducing methyl jasmonate 
combined with plant essential oils having fungicidal activity on $B$. cinerea growth; to determine the minimum effective concentration of any mixtures; and to determine the effects, if any, of the test mixtures on strawberry taste and shelf-life.

$\underline{\text { Materials and Methods }}$

Strawberries (Fragaria x ananassa Duch, Cv. Albion) packed in $454 \mathrm{~g}$ clamshells were acquired on the day of harvest from commercial growers in Santa Maria, California. Fabric bandages (Band-Aid's, Johnson and Johnson) size $10.2 \times 3.8 \mathrm{~cm}$ were used to deliver the plant volatile compounds 95\% methyl jasmonate and 95\% carvacrol (SigmaAldrich, St. Louis, MO), 99\% eugenol, 99\% thymol, 95\% citral, and 97\% linalool (Acros Organics, NJ) which were diluted in 99.5\% ethanol (Acros Organics, NJ). The dilutions were applied to the absorbent pad $(3.8 \times 2.5 \mathrm{~cm})$ of each bandage using a micropipette after which the bandage was affixed to the inner-surface of the clamshell lid.

Individual clamshells were overwrapped with a $0.0254 \mathrm{~mm}$ low density polyethylene (LDPE) film using a VELA 700 flowpack machine (Delfin srl, Malo, Vicenza, Italy). Four microperforations were made in the overwrap on the top side of each package using a \#7 syringe to prevent anaerobic storage conditions. Film permeability was measured using an 8001 Oxygen Permeation Analyzer (Systech Illinois, Johnsburg, IL) and a Mocon Permatron-c 4/41 (Minneapolis, MN). Packages were stored for 14 or 21 days at $4.4{ }^{\circ} \mathrm{C}$ and $95 \%$ humidity. The film had an $\mathrm{O}_{2}$ and $\mathrm{CO}_{2}$ permeability of 18,749 and $85,942 \mathrm{cc} / \mathrm{m}^{2} /$ day, respectively. 


\section{Microbial Studies}

A series of inoculation studies were conducted in both 2012 and 2013. The efficacy of volatile blends introduced to packages of fruit inoculated with Botrytis cinerea was determined. Botrytis was isolated from untreated strawberries using a sterile bacteriological loop and grown on Kritzman's agar at pH 5.0 (Kritzman and Netzer, 1978). A $1.0 \mathrm{~N} \mathrm{NaOH}$ (Fischer Scientific, Waltham, MA) solution was used to raise the $\mathrm{pH}$ of the agar to $\mathrm{pH} 5.0$.

Spore plates were held at $24{ }^{\circ} \mathrm{C}$ for $2-3$ weeks until full sporulation, at which time the plates were flooded with $10 \mathrm{~mL}$ of aqueous $0.01 \%$ polysorbate- 80 (Fisher Scientific, Waltham, MA). The plates were gently agitated to dislodge Botrytis spores and the suspension then filtered through a triple layer of sterile cheese cloth. The filtrate was quantified and adjusted to a concentration of $2 \times 10^{5}$ conidia/ mL using a hemacytometer. A Spectronic 20D spectrophotometer (Milton-Roy, Warminster, PA), was used in order streamline the dilution process for subsequent experiments. The absorbance of light at 8 different concentrations $\left(2 \times 10^{2}, 2 \times 10^{3}, 2 \times 10^{4} .2 \times 10^{5}, 4 \times 10^{5}, 8 \times 10^{5}, 1.6 \times 10^{6}\right.$, and $2 \times 10^{6}$ conidia/mL) was used to construct a calibration curve. Maximum absorption ( $\lambda \max )$ of the $2 \times 10^{5}$ conidia/mL diluent was determined to be $490 \mathrm{~nm}$.

Berry samples were sorted into a homogeneous group based on color and size before being disinfected in a $1 \%$ sodium hypochlorite solution for 2 minutes. Fruit were then triple rinsed with deionized (DI) water, air dried, then randomly distributed (10 or 12 berries per package depending on fruit size) into new clamshells. Each berry was 
inoculated with the $2 \times 10^{5}$ conidia/mL suspension by placing $50 \mu \mathrm{L}$ of the suspension on the fruit at the base of the calyx adjacent to the stem scar.

For each clamshell, $\mathrm{O}_{2}$ and $\mathrm{CO}_{2}$ levels were recorded immediately following overwrapping and daily thereafter. Gasses were measured using a Model 6600 headspace analyzer (Systech Illinois, Johnsburg, IL). Clamshells were examined daily to determine marketable shelf-life, defined as the number of days until one strawberry in the package had visible fungal growth, rot or excessive ( $>5 \%)$ tissue breakdown/wetting. After 14 or 21 days at $4.4^{\circ} \mathrm{C}$, the packages were opened to determine the number of rotted fruit in each clamshell. Fruit with visible mycelial growth or $>5 \%$ tissue breakdown/wetting were considered rotten. When rated, rot severity was estimated as the percentage of mycelial growth covering the total fruit surface within each clamshell.

\section{Brix and Titratable Acidity}

Soluble solids content (SSC) and titratable acidity (TA) were measured using juice from all the berries of a clamshell. Juice was expressed using a ricer and subsequently filtered through a triple layer of cheese cloth. A hand-held refractometer was used to measure soluble solids content. Titratable acidity was measured using a KEM cha-600 automatic titrator (Kyoto, Japan) with $0.1 \mathrm{~N} \mathrm{NaOH}$. Fifty $\mathrm{mL}$ of homogenized juice was diluted with $150 \mathrm{~mL}$ DI water to determine $\mathrm{g} / \mathrm{L}$ citric acid contained in each sample. Samples were run in triplicate. 


\section{Weight Loss During Storage}

Initial and final gross package weights were measured using a digital scale to determine percent water loss. Water loss was calculated by the formula:

Water Loss $_{\text {Total }}=\frac{\text { Gross Weight }_{I}}{\text { Gross Weight }_{I}}$-Gess Weight $_{F} \times 100 \%$

Experimental Design

A completely randomized design with a minimum of four replicates was used for each treatment in all experiments. Data were subjected to analysis of variance using the General Linear Model procedure (Proc GLM) in SAS 9.3 (SAS Institute, Cary, NC). Means were separated using Tukey's HSD mean separation test. Percent rot data were normalized using the cosine square-root function, when necessary. Simple regression analysis was conducted using SAS 9.3 (Proc Reg).

\section{Sensory Analysis}

A hedonic taste test was conducted to compare untreated strawberries with those treated with 2 volatile mixes that had shown the best efficacy against Botrytis: 600 ppm of a volatile mix (475.5 ppm EtOH; 60 ppm vanillin; 30 ppm citral; 30 ppm linalool; and 4.5 ppm methyl jasmonate) or $500 \mathrm{ppm}$ EtOH and methyl jasmonate (495.5 ppm; 4.5 ppm), respectively. Aroma, flavor, aftertaste, texture, appearance, and overall liking were determined on randomly-selected individual berries. The hedonic scale ranged from 1 to 9 with 1 indicating poorest quality and 9 indicating highest, for a particular factor. 
Since untrained tasters were used for this test, a large number of participants were required and 126 individuals participated in the taste test.

To simulate cross-country transit and distribution, the treated and untreated fruit were overwrapped and stored at $4.4{ }^{\circ} \mathrm{C}$ for a four-day period before being unwrapped and stored for $24 \mathrm{hr}$ at $4.4{ }^{\circ} \mathrm{C}$. On the day of testing, fruit were brought to room temperature $\left(21^{\circ} \mathrm{C}\right)$ before sampling. Tasting took place in private sensory booths with white fluorescent lighting. Filtered spring water and crackers without salted tops were provided as palate cleansers. Participants were prompted to complete a questionnaire on laptop computers for each treatment. Hedonic questionnaires were developed using the Compusense software package (Compusense, Inc., Guelph, Ontario, Canada).

\section{Gas Chromatograph (GC) Analysis}

Compounds used in the most efficacious formula from this study (methyl jasmonate, citral, linalool, vanillin) were tested for potential reduction of volatility due to mixing. Methyl jasmonate, citral, linalool, or vanillin was diluted $1 \mathrm{mg} / \mathrm{mL}$ in acetone and $100 \mu \mathrm{L}$ of a particular dilution was then applied onto filter paper $(1.5 \mathrm{~cm}$ diameter). The acetone was allowed to volatilize for $1 \mathrm{~min}$ before the filter paper was inserted into a $2 \mathrm{~mL} \mathrm{GC}$ vial. The vial was sealed and stored at $21{ }^{\circ} \mathrm{C}$ for $24 \mathrm{hr}$ before analysis.

Three replicates of each dilution were analyzed to determine retention times. Thereafter, all possible two-way combinations of methyl jasmonate, citral, linalool, and vanillin (100 $\mu \mathrm{L}$ of each dilution) were tested in triplicate to determine if any reductions 
in volatility occurred from mixing. A standard sample of $100 \mu \mathrm{L}$ of each individual compound was run before and after each blended sample.

Samples were analyzed using a Clarus 600/600C GC/mass spectrometer (MS)

(Perkin Elmer, Waltham, MA). Analysis was performed using a Restek RTX-502.2 (Bellefonte, PA), $30 \mathrm{~m} \mathrm{X} 0.25 \mathrm{~mm}$ (i.d.) fused silica capillary column with a film thickness of $1.4 \mu \mathrm{m}$. One $\mu \mathrm{L}$ samples were injected. The temperature program was 80 ${ }^{\circ} \mathrm{C}$ for 2 min followed by an increase of $20^{\circ} \mathrm{C} \mathrm{min}^{-1}$ for 11 minutes then a hold for 2 minutes. The inlet temperature was $250^{\circ} \mathrm{C}$, the ion source temperature was $250{ }^{\circ} \mathrm{C}$, the ionization energy was $71 \mathrm{eV}$, the emission current $300 \mu \mathrm{A}$, and the carrier gas was hydrogen. Retention times for methyl jasmonate, linalool, and vanillin were 9.13, 6.21, and $7.53 \mathrm{~min}$, respectively. Retention times for citral were $6.43 \mathrm{~min}$ for neral and 6.57 min for geranial.

\section{$\underline{\text { Results and Discussion }}$}

In the 2011 season, trials were designed to optimize the levels of methyl jasmonate and EtOH required to significantly reduce the incidence of Botrytis on harvested 'Albion' strawberries. Previous studies had reported variations in methyl jasmonate efficacy between rot-susceptible and resistant strawberry cultivars harvested late in the season after rains (Moline et al., 1997). Five-hundred ppm EtOH with 4.5 ppm methyl jasmonate resulted in significantly fewer rotten fruit compared to the untreated check (Table 1). This treatment also tended to result in fruit with the longest shelf-life in the trial series. 
A pronounced strawberry scent emanated from overwrapped clamshells subjected to $\geq 250 \mathrm{ppm} \mathrm{EtOH}$, and the scent appeared to increase in intensity and complexity when $\geq 250 \mathrm{EtOH}$ was combined with any amount of methyl jasmonate. This effect of methyl jasmonate on strawberries has been subjectively observed (Moline et al., 1997) and quantified (de la Peña Moreno et al., 2010a). Ayala-Zavala et al. (2005) found that treating strawberries with both $\mathrm{EtOH}$ and $\mathrm{EtOH}$ combined with methyl jasmonate significantly increased methyl and ethyl esters and had a positive effect on shelf-life.

The application of 375 ppm EtOH, 4.5 ppm methyl jasmonate, 125 ppm carvacrol, $60 \mathrm{ppm}$ thymol and $125 \mathrm{ppm}$ eugenol tended to result in the lowest incidence of Botrytis rot during the 2011 shelf-life trials. Strawberries treated with this formulation had less rotted fruit (24.2\%) than untreated berries (45.5\%) after $14 \mathrm{~d}$ storage at $4.4{ }^{\circ} \mathrm{C}$ (Table 2). Berries treated with this blend also tended to have the longest shelf-life of 11.3 days (Table 2). Similar studies found a 75.8\% (Bhaskara Reddy et al., 1998) and 90\% (AbdAlla et al., 2011) reduction in the incidence of grey mold on inoculated strawberries treated with 200 ppm thyme oil.

Volatile treatments were found to be phytotoxic to the calyxes after approximately 710 days of storage at $4.4^{\circ} \mathrm{C}$ (Fig. 8). However, strawberries treated with $200 \mathrm{ppm}$ of two different thyme-oil extracts were reported to have no visible phytotoxic symptoms after 14 days of storage at $13{ }^{\circ} \mathrm{C}$ (Bhaskara Reddy et al., 1998). Researchers also observed that methyl jasmonate prevented the phytotoxic browning of cherry stems caused by carvacrol and thymol applications (Tsao and Zhou, 2000). No protective effect of methyl 
jasmonate was observed in any trial in the study reported herein. Any chemical treatment at $\geq 100 \mathrm{ppm}$ eventually resulted in the drying of the calyx.

\section{Inoculation Studies}

Strawberries treated with 600 ppm EtOH, 3.5 ppm methyl jasmonate, 100 ppm citral, and $100 \mathrm{ppm}$ linalool tended to have the lowest percent rot and longest shelf life in the inoculation studies (Table 3). This combination significantly reduced the incidence of grey mold with $33.3 \%$ rotten fruit 14 dyas after inoculation compared to the untreated check at $100 \%$ infected fruit, $\mathrm{EtOH}$ at $73 \%$, and $\mathrm{EtOH}$ plus methyl jasmonate at $68.8 \%$

respectively. A similar study indicated a $90 \%$ reduction in the incidence of grey mold on inoculated strawberries with the addition of $200 \mathrm{ppm}$ of lemongrass oil (Abd-Alla et al., 2011).

Combinations that contained citral and linalool applied at $\geq 200$ ppm per package inhibited grey mold (Table 3) but were found to have a phytotoxic effect on both the strawberry calyx and fruit (Fig. 9). Calyxes had a desiccated appearance after a few days storage and affected fruit had softened flesh and a wet appearance after approximately 10-12 days of storage at $4.4{ }^{\circ} \mathrm{C}$. Citral has been shown to be more phytotoxic than carvacrol or thymol to tomato fruit (Plotto et al., 2003). This may explain why similar application levels of carvacrol and/or thymol were only phytotoxic to the strawberry calyxes. 


\section{Trials}

Strawberries treated with 495.5 ppm EtOH, 4.5 ppm methyl jasmonate, 30 ppm citral, $30 \mathrm{ppm}$ linalool, and $60 \mathrm{ppm}$ vanillin had less rot than untreated fruit after 21 days storage (Fig. 10,11), with treated fruit having $20.6 \%$ rot compared to $68.8 \%$ for the controls (Table 4). In vitro studies reported a synergy between vanillin and lavender oil (linalool) in inhibiting the growth of Botrytis cinerea (Rattanapitigorn et al., 2006). The shelf-life of fruit treated with this volatile combination was also 9.7 days longer than fruit from the untreated check (Table 4), and it was subjectively observed to have less impact on strawberry flavor compared to treatments that contained carvacrol, thymol, and eugenol.

Overwrapped clamshells containing strawberries treated with $\mathrm{EtOH}$ at a rate of $\geq 250$ ppm contained less oxygen immediately after treatment compared to overwrapped controls, suggesting an increase in fruit respiration. In contrast, Almenar et al. (2009) found that increasing concentrations of 2-nonanone were correlated with reduced wood strawberry (Fragaria vesca) respiration rates. In the study herein, headspace oxygen levels were significantly correlated to the volume of EtOH added (Fig. 12). Carbon dioxide levels were not correlated to EtOH levels. Oxygen levels tended to remain reduced while $\mathrm{CO}_{2}$ levels increased slightly throughout the storage period (data not shown). To our knowledge, this phenomenon has not been observed in other studies.

The increase in fruit respiration through the addition of EtOH did not result in a reduction of shelf-life, or increase in decay, as higher treatment levels of EtOH often 
tended to extend shelf-life and reduce decay. The thin LDPE film used in this study had nearly 4 to 6 times greater permeability for $\mathrm{CO}_{2}\left(85,942 \mathrm{cc} / \mathrm{m}^{2} /\right.$ day $)$ compared to $\mathrm{O}_{2}$ $\left(18,749 \mathrm{cc} / \mathrm{m}^{2} / \mathrm{day}\right)$. Carbon dioxide has a higher permeability rate through polymer films compared to $\mathrm{O}_{2}$, and similar transmission rates through1 mil LDPE have been reported in other studies (Bixler and Sweeting, 1971). The excessive permeability of LDPE to $\mathrm{CO}_{2}$ may explain why $\mathrm{CO}_{2}$ levels did not increase in the packages even though fruit respiration increased as was indicated by the reduced $\mathrm{O}_{2}$ levels.

Fruit treated with $500 \mathrm{ppm}$ EtOH had significantly lower SSC than untreated fruit after 14 days of storage at $4.4^{\circ} \mathrm{C}$ (Table 4). In contrast, Ayala-Zavala et al. (2005) observed increases in both strawberry SSC and TA four days after treatment with 400 ppm EtOH and the levels remained elevated throughout the 13 day trial. Fruit subjected to treatments that contained $500 \mathrm{ppm} \mathrm{EtOH}$ plus essential-oil volatiles were not reduced in SSC suggesting the differences may have been due to natural variation among samples.

Simple regression analysis indicated that percent rot, days of shelf-life, rot severity, and days before calyx browning were correlated to the treatment level of a $79.95 \% \mathrm{v} / \mathrm{v}$ EtOH, $10 \%$ v/v vanillin, $5 \%$ v/v citral, $5 \%$ v/v linalool, and $0.05 \%$ v/v methyl jasmonate blend (Fig. 13). Individual packages of fruit were treated with 0-1200 ppm of the mix and levels were increased in 50 ppm increments. Application of 1000-1200 ppm of this mixture resulted in the complete inhibition of grey mold on inoculated fruit for 17 days at $4.4{ }^{\circ} \mathrm{C}$ (Fig. 13). However, strawberries exposed to $\geq 750 \mathrm{ppm}$ had desiccated calyxes after only three days of storage at $4.4^{\circ} \mathrm{C}$ (Fig. 13). 
In contrast, the rot incidence, severity, and number of days before calyx desiccation were all negatively correlated with the mixture containing $79.95 \% \mathrm{v} / \mathrm{v} \mathrm{EtOH}, 10 \% \mathrm{v} / \mathrm{v}$ vanillin, $5 \%$ v/v citral, $5 \%$ v/v linalool, and $0.05 \%$ v/v methyl jasmonate. The $R^{2 \text { s }}$ were $0.80,0.83$, and 0.84 , respectively (Fig. 13). Shelf-life had a significant positive correlation to ppm of the mixture and fruit treated with 900-1200 ppm of the formula had no visible mycelial growth after 17 days of storage at $4.4{ }^{\circ} \mathrm{C}$.

Researchers have observed significant reductions in the volatility of both methyl jasmonate (61\%) and thymol (60\%) after blending (Tsao and Zhou, 2000). In this study, two-way combinations of methyl jasmonate, linalool, citral, or vanillin resulted in reduced volatility of the components (Table 5). New or unexplained peaks were not observed from blending the compounds suggesting that the reduction of volatility was likely due to blending and not a chemical reaction.

A hedonic taste test was conducted on July 10, 2013 to compare untreated strawberries to those treated with $600 \mathrm{ppm}$ of a volatile formulation $(475.5 \mathrm{ppm} \mathrm{EtOH}$; 60 ppm vanillin; 30 ppm citral; 30 ppm linalool; 4.5 ppm methyl jasmonate) and fruit treated with $495.5 \mathrm{ppm}$ EtOH plus $4.5 \mathrm{ppm}$ methyl jasmonate. Aroma, flavor, aftertaste, texture, appearance, and overall liking were all determined on individual berries randomly selected from the three treatments.

Fruit treated with 600 ppm EtOH, vanillin, citral, linalool, and methyl jasmonate had a less acceptable flavor, texture, aftertaste, and appearance compared to the untreated 
fruit (Table 6). Overall liking of the fruit treated with essential-oils was also less than untreated fruit though it averaged about one point less on the hedonic scale overall. The treatments had no effect on aroma acceptability (Table 6).

The scores for flavor or aftertaste of fruit treated with $500 \mathrm{ppm}$ of EtOH plus methyl jasmonate were not different than that of untreated fruit (Table 6). However, fruit treated with EtOH plus methyl jasmonate had lower scores for appearance, aftertaste, and overall liking compared to untreated fruit. Fruit treated with EtOH plus methyl jasmonate scored significantly higher for flavor, texture, aftertaste, and overall liking compared to fruit treated with EtOH, vanillin, citral, linalool, and methyl jasmonate but were not significantly different in appearance.

The aftertaste of essential-oil compounds was detected by many of the participants in this study $24 \mathrm{hr}$ after the film overwraps were removed. In contrast, sensory analysis of table grapes in a similar study found that $90 \%$ of trained taste panelists could not detect the presence of a mix of $75 \mathrm{ppm}$ carvacrol, thymol, and eugenol after overwrapped packages of table grapes were left open for "a while" (Guillen et al., 2007). This may have been due to higher treatment levels (600 ppm vs. $75 \mathrm{ppm}$ ) used in this study and the higher respiration levels of strawberries compared to table grapes (Saltveit, 2004). A longer storage period before the sensory test might have resulted in essential oil or EtOH plus methyl jasmonate-treated fruit receiving higher scores compared to untreated fruit, due to the preservative effects of these treatments. 
Regardless of volatile treatment, weight loss from the strawberries was minimal with total weight loss typically averaging $2 \%$ or less (data not shown). A $2 \%$ loss of water is not detrimental to strawberry fruit quality or shelf-life as $6 \%$ is the threshold for loss of strawberry fruit quality (Robinson et al., 1975). Water loss was likely minimal because fruit remained overwrapped in a micro-perforated polyethylene film during storage.

Sixty experiments were conducted over the course of three harvest seasons. Hundreds of combinations and treatment levels of essential-oil compounds were tested in an effort to identify a consistently effective blend (Table 7). Treatment combinations containing a mix of of EtOH, vanillin, citral, linalool, and methyl jasmonate (500-1200 ppm) were the most effective blends to reduce rot and increase shelf-life, overall. Strawberries treated with $600 \mathrm{ppm}$ of this blend were slightly less acceptable in organoleptic quality. However, fruit treated with this volatile formula have the potential for a significantly longer shelf-life than untreated fruit, a benefit to shippers, retailers, and consumers. Applications of essential-oil constituents were found to be most beneficial later in the picking season when disease pressure from B.cinerea was much higher (data not shown).

The results of this study confirm that a blend of essential-oil volatiles -- EtOH, vanillin, citral, linalool, and methyl jasmonate -- with different modes of action can significantly reduce the incidence of $B$. cinerea after harvest and extend the shelf-life of strawberries. Investigations into other methods of application such as treating fruit temporarily in a fumigation chamber may further increase the efficacy of this blend, as 
researchers have observed a complete inhibition of grey mold on strawberries for 14 days at $5{ }^{\circ} \mathrm{C}$ after fumigation with $5.4 \mathrm{mg} / \mathrm{mL}$ acetic acid (Moyls et al., 1996). Short-term fumigation of fruit may therefore eliminate the phytotoxic effect of this blend on the calyxes and the slightly negative organoleptic effects. 
Table 1. Effect of volatile compounds on the incidence of Botrytis cinerea of strawberries indicated by percent rot and days shelf-life, 2011.

\begin{tabular}{|c|c|c|c|c|}
\hline \multirow[b]{2}{*}{ Treatment } & \multicolumn{2}{|c|}{ September 12-26 } & \multicolumn{2}{|c|}{ September 19-October 3} \\
\hline & $\begin{array}{c}\text { Percent rot } \\
\text { after } 14 \text { days }\end{array}$ & $\begin{array}{l}\text { Shelf life } \\
\text { at } 4.4^{\circ} \mathrm{C} \\
\end{array}$ & $\begin{array}{c}\text { Percent rot } \\
\text { after } 14 \text { days }\end{array}$ & $\begin{array}{l}\text { Shelf life } \\
\text { at } 4.4^{\circ} \mathrm{C}\end{array}$ \\
\hline $\mathrm{UTC}^{\mathrm{z}}$ & $82.5 \mathrm{a}^{\mathrm{y}}$ & $8.0 \mathrm{ab}$ & $82.7 \mathrm{a}$ & $6.0 \mathrm{a}$ \\
\hline $250 \mathrm{ppm}^{\mathrm{x}} \mathrm{EtOH}$ & $75.7 \mathrm{ab}$ & $10.0 \mathrm{ab}$ & $62.3 \mathrm{a}$ & $7.8 \mathrm{a}$ \\
\hline 250 ppm EtOH:0.5 ppm MJ & $61.0 \mathrm{ab}$ & $8.8 \mathrm{ab}$ & $50.5 \mathrm{~b}$ & $7.8 \mathrm{a}$ \\
\hline 250 ppm EtOH:4.5 ppm MJ & $62.4 \mathrm{ab}$ & $7.0 \mathrm{~b}$ & $51.9 \mathrm{ab}$ & $7.3 \mathrm{a}$ \\
\hline 250 ppm EtOH:45 ppm MJ & $58.2 \mathrm{ab}$ & $12.3 \mathrm{ab}$ & $52.2 \mathrm{ab}$ & $8.5 \mathrm{a}$ \\
\hline 500 ppm EtOH & $50.6 \mathrm{ab}$ & $8.0 \mathrm{ab}$ & $47.6 \mathrm{~b}$ & $8.0 \mathrm{a}$ \\
\hline 500 ppm EtOH:0.5 ppm MJ & $55.7 \mathrm{ab}$ & $11.3 \mathrm{ab}$ & $41.1 \mathrm{~b}$ & $9.5 \mathrm{a}$ \\
\hline 500 ppm EtOH:4.5 ppm MJ & $43.9 \mathrm{~b}$ & $13.3 \mathrm{a}$ & $38.1 \mathrm{~b}$ & $9.5 \mathrm{a}$ \\
\hline 500 ppm EtOH:45 ppm MJ & $57.0 \mathrm{ab}$ & $11.0 \mathrm{ab}$ & $47.6 \mathrm{~b}$ & $8.5 \mathrm{a}$ \\
\hline
\end{tabular}

${ }^{\mathrm{z}} \mathrm{UTC}=$ untreated control; $\mathrm{MJ}=$ methyl jasmonate; EtOH=ethanol.

${ }^{y}$ Means with the same letter are not significantly different at the $95 \%$ confidence level according to Tukey’s HSD Mean Separation Test.

${ }^{\mathrm{x}}$ Parts per million of compounds used to treat a $454 \mathrm{~g}$ overwrapped clamshell. 
Table 2. Days of shelf-life and \% rot of un-inoculated strawberries after 14 days at $4.4^{\circ} \mathrm{C}$ : November 7 to December 15, 2011.

\begin{tabular}{|c|c|c|}
\hline Treatment & $\begin{array}{c}\text { Percent } \\
\text { rot after } \\
14 \text { days }\end{array}$ & $\begin{array}{r}\text { Shelf-life } \\
\text { at } 4.4^{\circ} \mathrm{C}\end{array}$ \\
\hline $\mathrm{UTC}^{\mathrm{z}}$ & $45.5 \mathrm{a}^{\mathrm{y}}$ & $9.4 \mathrm{a}$ \\
\hline 375 ppm $^{\mathrm{x}} \mathrm{EtOH}$ & $34.5 \mathrm{ab}$ & $9.1 \mathrm{a}$ \\
\hline 375 ppm EtOH:4.5 ppm MJ & $30.2 \mathrm{~b}$ & $9.3 \mathrm{a}$ \\
\hline 375 ppm EtOH:4.5 ppm MJ:375 ppm CV & $30.7 \mathrm{~b}$ & $9.5 \mathrm{a}$ \\
\hline 375 ppm EtOH:4.5 ppm MJ:125 ppm CV:125 ppm TY:125 ppm EU & $24.2 \mathrm{~b}$ & $11.3 \mathrm{a}$ \\
\hline
\end{tabular}

${ }^{\mathrm{z}} \mathrm{CV}=$ carvacrol; $\mathrm{ETOH}=$ ethanol; EU = eugenol; $\mathrm{MJ}=$ methyl jasmonate; $\mathrm{TY}=$ thymol; $\mathrm{UTC}=$ untreated control.

y Means with the same letter are not significantly different at the $95 \%$ confidence level according to Tukey's HSD Mean Separation Test.

${ }^{\mathrm{x}}$ Parts per million of compounds used to treat a 454g overwrapped clamshell. 


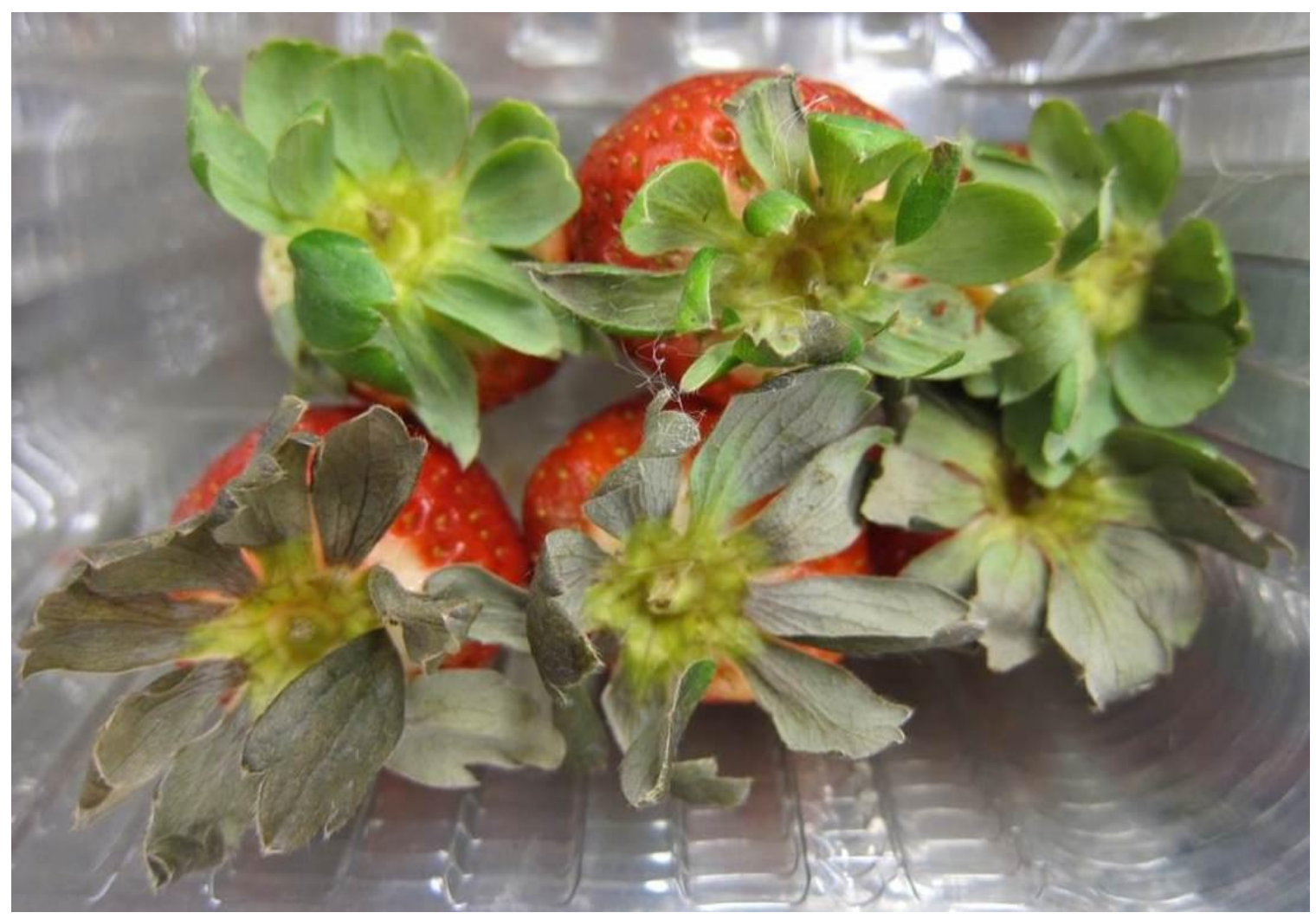

Fig. 8. The phytotoxic effect of volatile treatments on strawberry calyxes exposed to ethanol and the essential-oil compounds carvacrol, thymol, and eugenol for 14 days at $4.4{ }^{\circ} \mathrm{C}$. 
Table 3. Days of shelf-life and percent rot of strawberries 14 days after inoculation with Botrytis cinerea. Berries were held at $4.4^{\circ} \mathrm{C}$.

\begin{tabular}{lcr}
\hline \hline Treatment & $\begin{array}{c}\text { Percent rot } \\
\text { after 14 days }\end{array}$ & $\begin{array}{r}\text { Shelf life } \\
\text { at } 4.4^{\circ} \mathrm{C}\end{array}$ \\
\hline $\mathrm{UTC}^{\mathrm{z}}$ & $100.0 \mathrm{a}^{\mathrm{y}}$ & $6.3 \mathrm{c}$ \\
$400 \mathrm{ppm}^{\mathrm{x}} \mathrm{EtOH}$ & $73.0 \mathrm{~b}$ & $7.5 \mathrm{bc}$ \\
$400 \mathrm{ppm} \mathrm{EtOH:3.5} \mathrm{ppm} \mathrm{MJ}$ & $68.8 \mathrm{bc}$ & $9.0 \mathrm{~b}$ \\
$400 \mathrm{ppm}$ EtOH:100 ppm CT:100 ppm LN:3.5 ppm MJ & $62.5 \mathrm{c}$ & $13.5 \mathrm{a}$ \\
$600 \mathrm{ppm}$ EtOH:100 ppm CT:100 ppm LN:3.5 ppm MJ & $33.3 \mathrm{~d}$ & $13.8 \mathrm{a}$ \\
\end{tabular}

${ }^{\mathrm{z}} \mathrm{UTC}=$ untreated control; $\mathrm{CT}=$ citral $; \mathrm{EtOH}=$ ethanol; $\mathrm{LN}=$ linalool; $\mathrm{MJ}=$ methyl jasmonate

${ }^{y}$ Means with the same letter are not significantly different at the $95 \%$ confidence level according to Tukey’s HSD Mean Separation Test.

${ }^{\mathrm{x}}$ Parts per million of compounds used to treat a 454g overwrapped clamshell. 


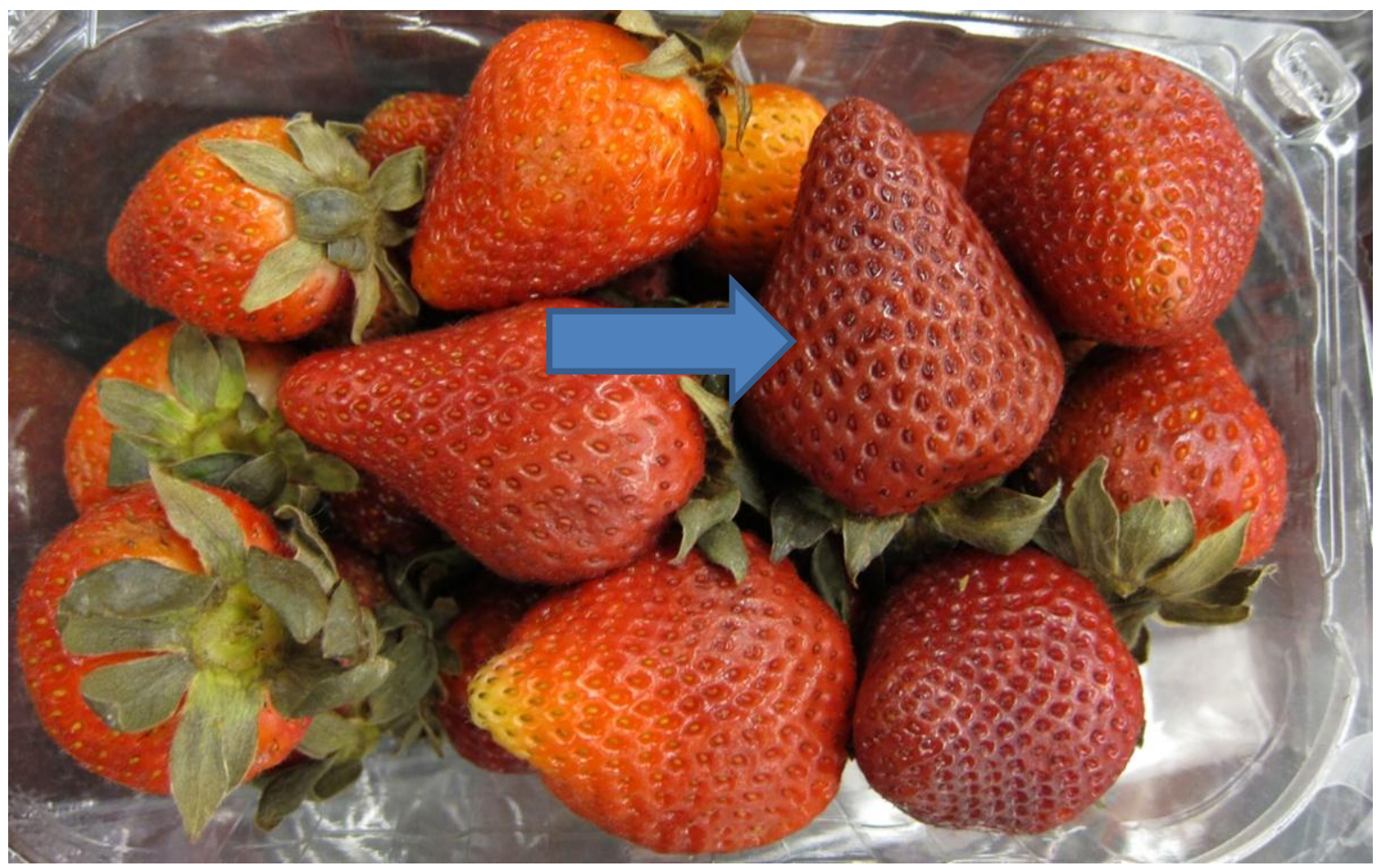

Fig. 9. The phytotoxic effect of high levels $(200 \mathrm{ppm})$ of citral and linalool on strawberry fruit after 14 days of exposure. 
Table 4. Days of shelf-life, percent rot after 21 days at $4.4^{\circ} \mathrm{C}$, soluble solids, and total titratable acidity of un-inoculated strawberries.

\begin{tabular}{|c|c|c|c|c|c|c|}
\hline \multirow[b]{2}{*}{ Treatment } & \multirow{2}{*}{$\begin{array}{l}\text { Percent rot } \\
\text { after } 21 \text { days }\end{array}$} & \multirow{2}{*}{$\begin{array}{l}\text { Shelf-life } \\
\text { at } 4.4{ }^{\circ} \mathrm{C} \\
\end{array}$} & \multicolumn{2}{|c|}{$\begin{array}{c}\text { Soluble } \\
\text { solids }(\%)\end{array}$} & \multicolumn{2}{|c|}{ Total acid $(\mathrm{g} / \mathrm{L})$} \\
\hline & & & day 7 & day14 & day 7 & day 14 \\
\hline $\mathrm{UTC}^{\mathrm{z}}$ & $68.8 \mathrm{a}^{\mathrm{y}}$ & $10.8 \mathrm{c}$ & $8.8 \mathrm{a}$ & $7.8 \mathrm{a}$ & $8.1 \mathrm{c}$ & $8.7 \mathrm{bc}$ \\
\hline $500 \mathrm{ppm}^{\mathrm{x}} \mathrm{EtOH}$ & $43.2 \mathrm{ab}$ & $15.7 \mathrm{~b}$ & $8.8 \mathrm{a}$ & $6.9 \mathrm{~d}$ & $8.7 \mathrm{~b}$ & $8.9 \mathrm{ab}$ \\
\hline 500 ppm EtOH:MJ ${ }^{\mathrm{w}}$ & $40.4 \mathrm{~b}$ & $14.8 \mathrm{~b}$ & $8.4 \mathrm{ab}$ & $7.3 \mathrm{c}$ & $8.4 \mathrm{bc}$ & $8.6 \mathrm{bc}$ \\
\hline 560 ppm EtOH:MJ:VN:LN & $\mathrm{N} 28.0 \mathrm{~b}$ & $17.8 \mathrm{ab}$ & $7.4 \mathrm{c}$ & $7.5 \mathrm{~b}$ & $8.2 \mathrm{c}$ & $9.3 \mathrm{a}$ \\
\hline 530 ppm EtOH:MJ:VN & $24.6 \mathrm{~b}$ & $15.7 \mathrm{~b}$ & $8.0 \mathrm{~b}$ & $7.8 \mathrm{a}$ & $9.1 \mathrm{a}$ & $8.6 \mathrm{bc}$ \\
\hline 590 ppm EtOH:MJ: & $20.6 \mathrm{~b}$ & $20.5 \mathrm{a}$ & $8.0 \mathrm{~b}$ & $7.4 \mathrm{~b}$ & $9.6 \mathrm{a}$ & $8.2 \mathrm{c}$ \\
\hline \multicolumn{7}{|l|}{ VN:LN:CT } \\
\hline \multicolumn{7}{|c|}{$\overline{\mathrm{z}} \mathrm{UTC}=$ untreated control; $\mathrm{CT}=$ citral; $\mathrm{EtOH}=$ ethanol; $\mathrm{LN}=$ linalool; $\mathrm{MJ}=$ methyl } \\
\hline \multicolumn{7}{|c|}{${ }^{\mathrm{y}}$ Means with the same letter are not significantly different at the $95 \%$ confidence level } \\
\hline \multicolumn{7}{|c|}{ according to Tukey's HSD Mean Separation Test. } \\
\hline \multicolumn{7}{|c|}{ x Parts per million of compounds or blends used to treat a $454 \mathrm{~g}$ overwrapped clamshell. } \\
\hline \multicolumn{7}{|c|}{ w 500 ppm EtOH:MJ = 495.5 ppm EtOH, 4.5 ppm MJ; } \\
\hline \multicolumn{7}{|c|}{530 ppm EtOH:MJ:VN = 495.5 ppm EtOH, 4.5 ppm MJ, 30 ppm vanillin; } \\
\hline \multicolumn{7}{|c|}{560 ppm EtOH:MJ:VN:LN = 495.5 ppm EtOH, 4.5 ppm MJ, 30 ppm vanillin, 30 ppm } \\
\hline \multicolumn{7}{|l|}{ linalool; } \\
\hline 590 ppm EtOH:MJ:VN:I & $: \mathrm{LN}: \mathrm{CT}=495$ & $.5 \mathrm{ppm} \mathrm{EtC}$ & $\mathrm{H}, 4.5 \mathrm{pl}$ & $\mathrm{MJ}, 30$ & pm vani & lin, 30 \\
\hline
\end{tabular}




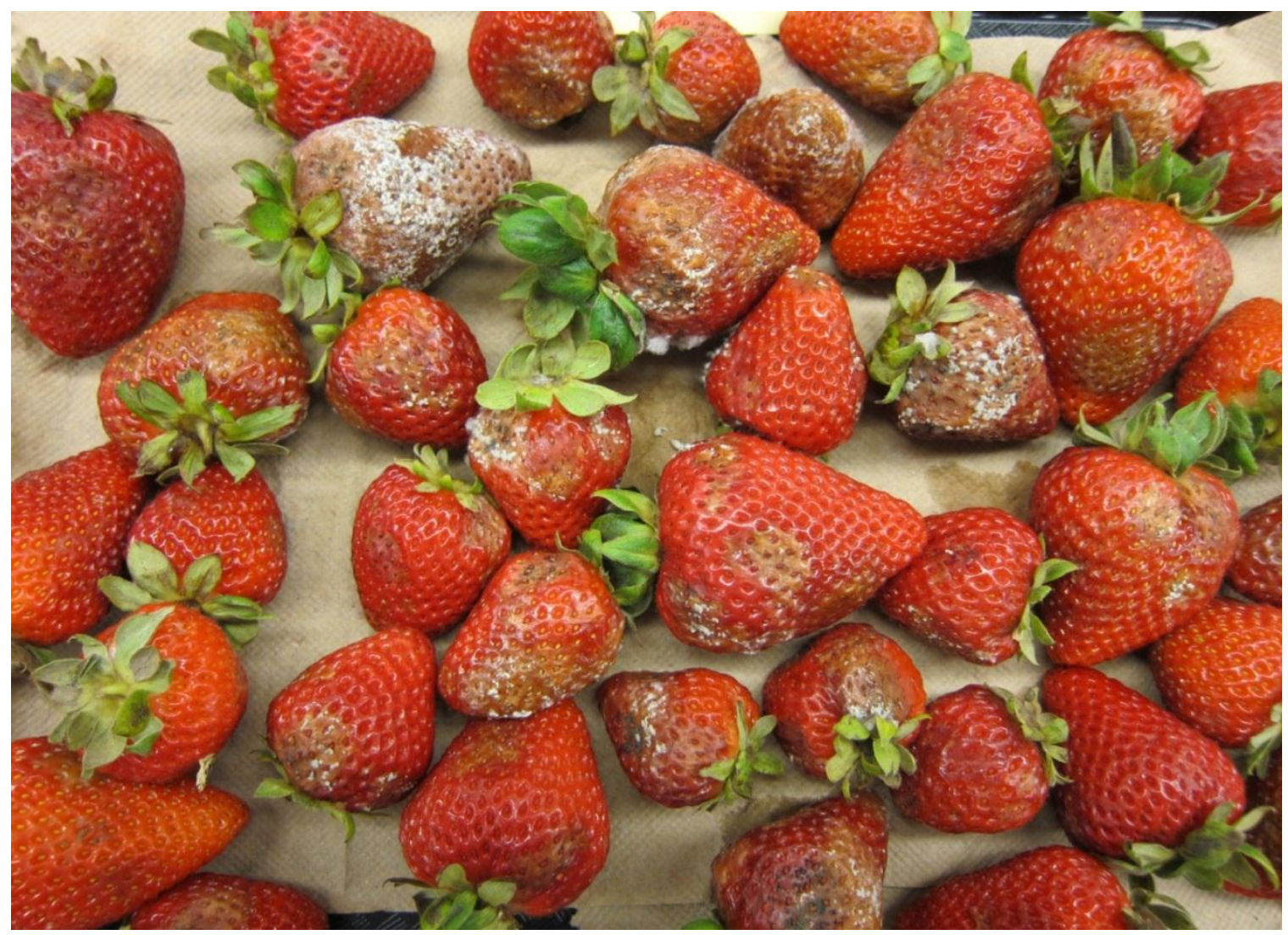

Fig. 10. Untreated fruit after 21 days of storage at $4.4^{\circ} \mathrm{C}$ showing excessive rot due to Botrytis cinerea. 


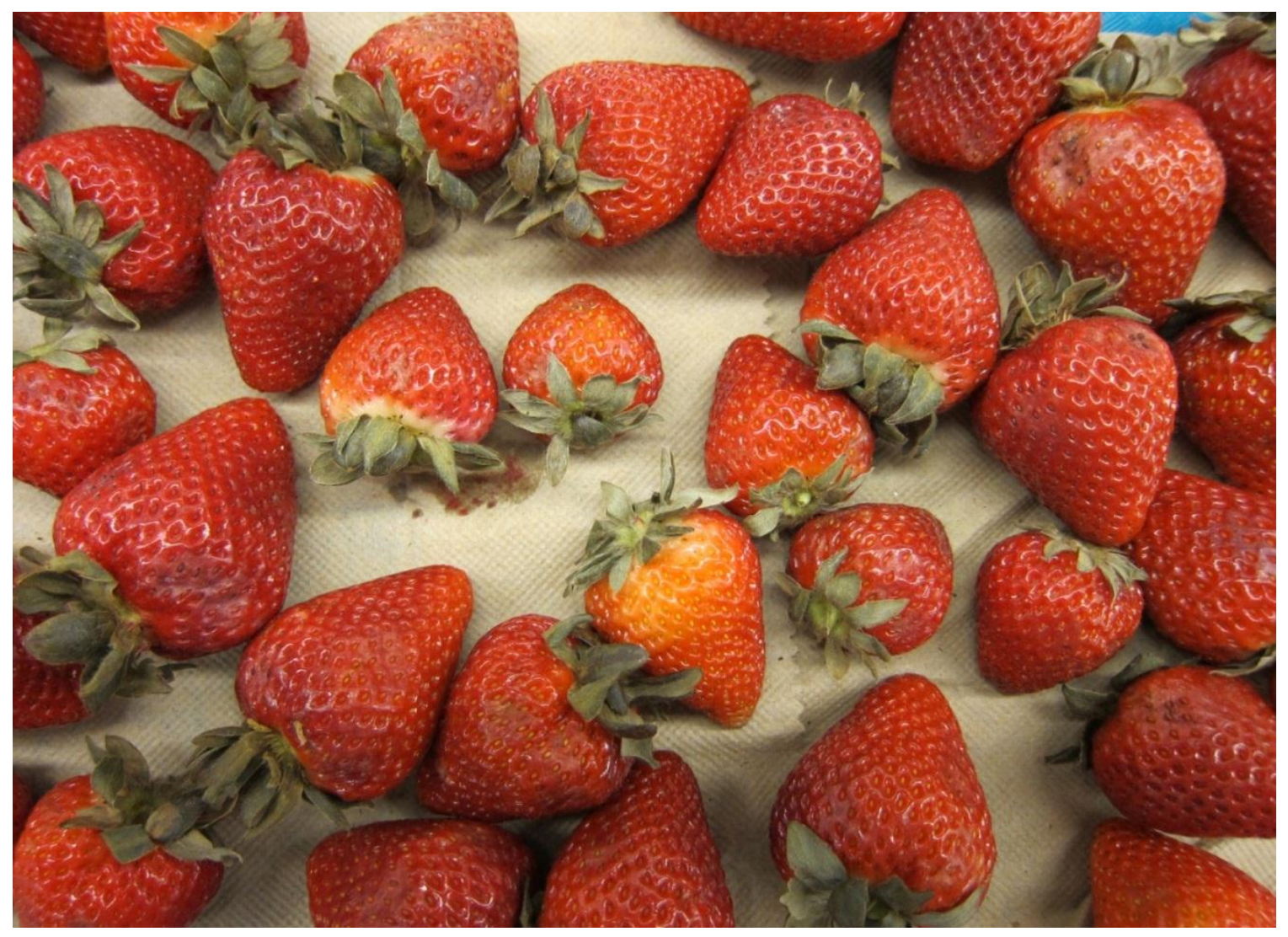

Fig. 11. Fruit treated with $590 \mathrm{ppm}$ of EtOH, vanillin, citral, linalool and methyl jasmonate 21 days after treatment at $4.4{ }^{\circ} \mathrm{C}$. 


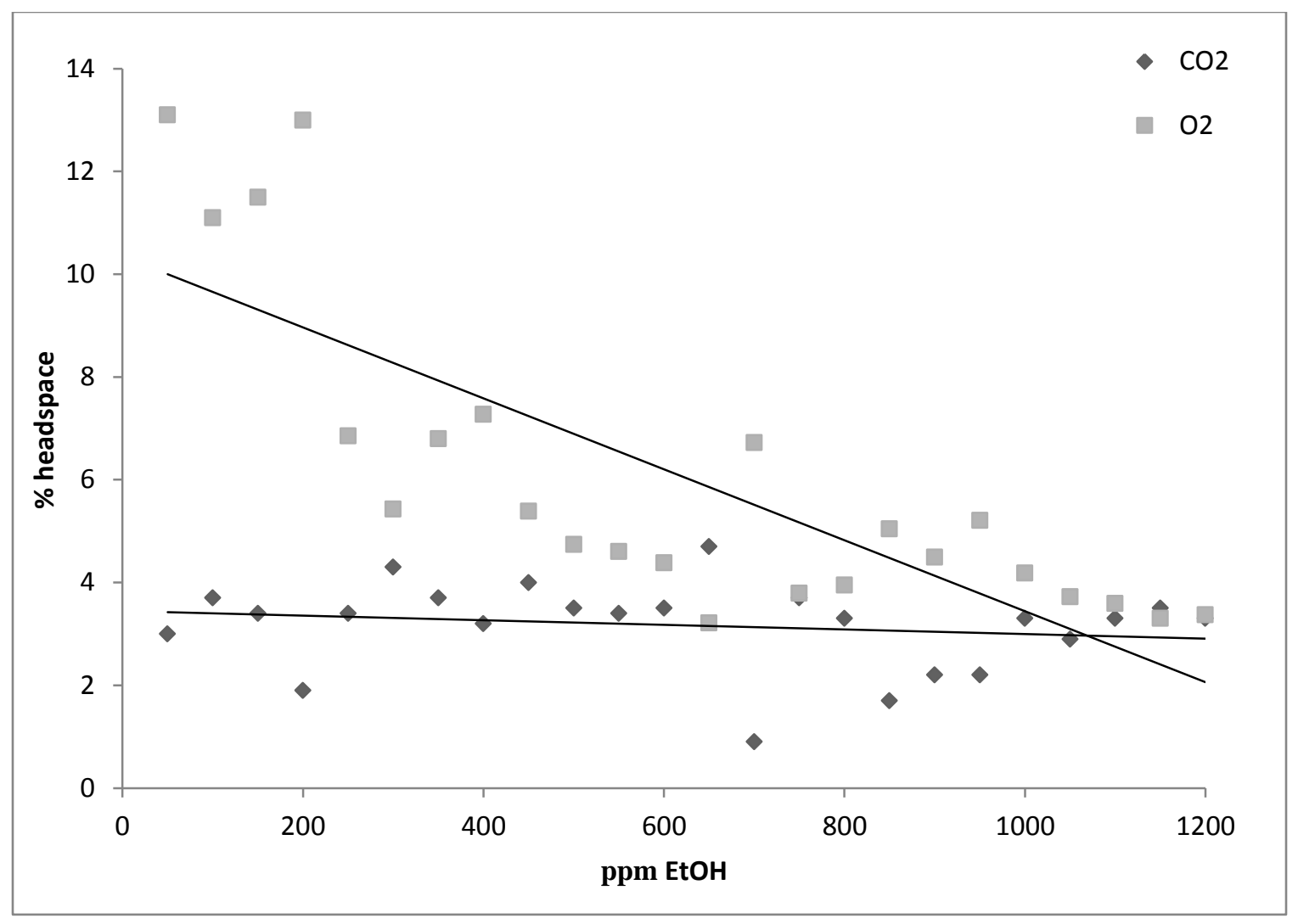

Fig. 12. Ethanol effects on strawberry headspace oxygen levels immediately after treatment. Headspace oxygen $(r=0.80)$ and carbon dioxide of overwrapped strawberry packages treated with 0-1200 ppm of EtOH in 50 ppm increments. 


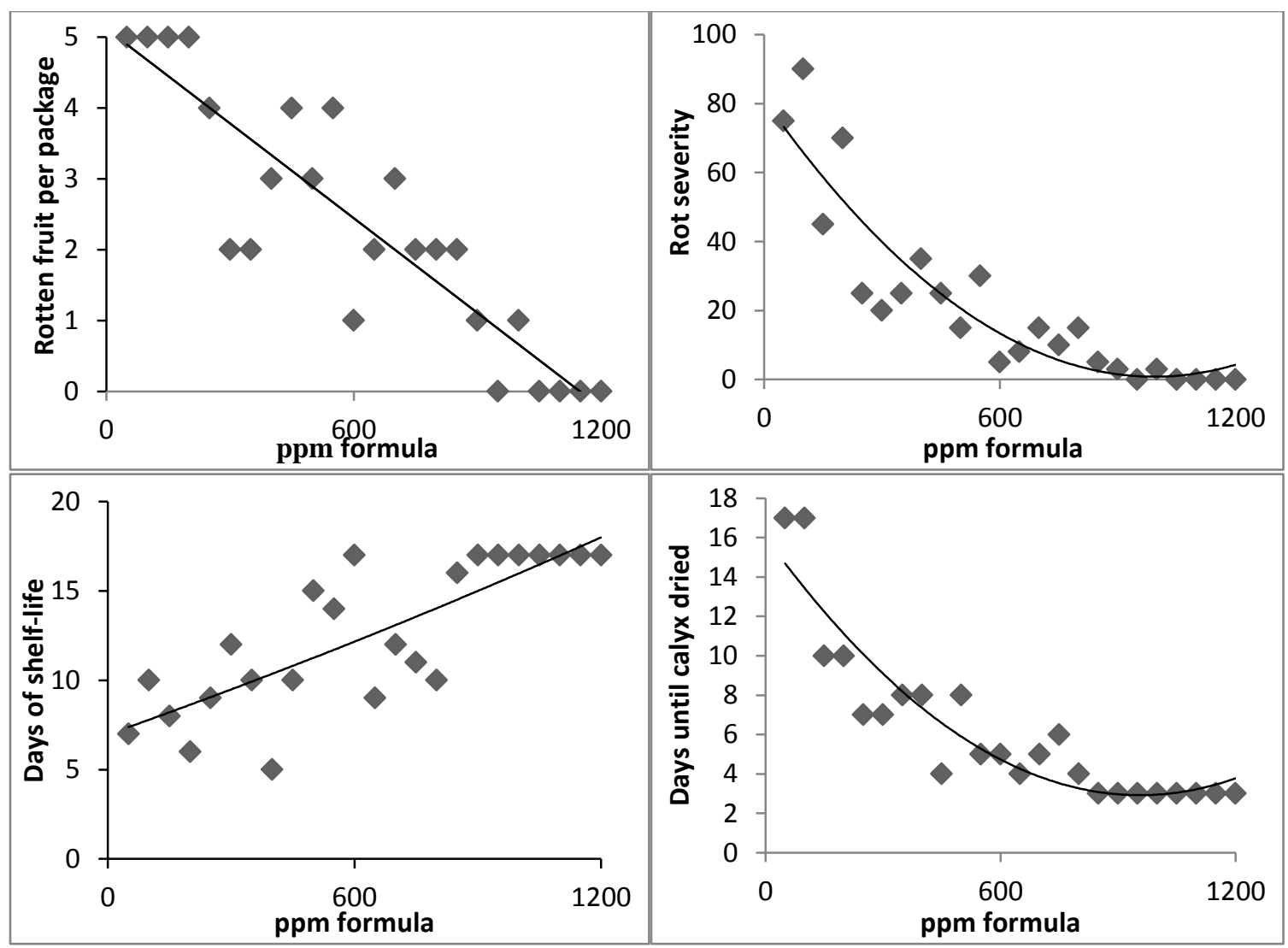

Fig. 13. Regression analysis of the percent rotten fruit $(r=0.89)$, rot severity $\quad(r=$ $0.91)$, days shelf-life $(r=0.80)$, and days until calyx dried $(r=0.92)$ of fruit inoculated with Botrytis cinerea. Fruit were treated with $0-1200 \mathrm{ppm}$ of a 79.95 $\%$ v/v EtOH, $10 \%$ v/v vanillin, $5 \%$ v/v citral,5\% v/v linalool, and $0.05 \%$ v/v methyl jasmonate blend. Trial ended 17 days after inoculation. 
Table 5. Effect of mixing plant essential oils on their volatility compared to the pure standards.

\begin{tabular}{|c|c|c|c|c|}
\hline \multirow[b]{2}{*}{ Compound } & \multicolumn{4}{|c|}{$\%$ Reduction After Mixing With: } \\
\hline & $\mathrm{MJ}^{\mathrm{y}}$ & $\mathrm{LN}$ & $\mathrm{CT}$ & $\mathrm{VN}$ \\
\hline Methyl jasmonate ${ }^{\mathrm{z}}$ & - & $54.7 \%$ & $41.9 \%$ & $51.9 \%$ \\
\hline Linalool & $56.8 \%$ & - & $50.1 \%$ & $58.9 \%$ \\
\hline Citral: Neral & $42.8 \%$ & $53.1 \%$ & - & $46.4 \%$ \\
\hline Citral: Geranial & $41.0 \%$ & $52.3 \%$ & - & $49.6 \%$ \\
\hline Vanillin & $52.2 \%$ & $62.0 \%$ & $44.7 \%$ & - \\
\hline
\end{tabular}

${ }^{\mathrm{z}}$ Peak area of $100 \mu \mathrm{L}$ of a sample containing $1 \mathrm{mg}$ standard $/ \mathrm{mL}$ in acetone.

${ }^{\mathrm{y}} \mathrm{MJ}=$ methyl jasmonate; $\mathrm{LN}=$ linalool; $\mathrm{CT}=$ citral; $\mathrm{VN}=$ vanillin. 
Table 6. Sensory analysis results for hedonic test conducted on July 10, 2013.

Overall $\underline{\text { Treatment }}$ Aroma Appearance Flavor Texture Aftertaste Liking

$\begin{array}{lllllll}\text { UTC }^{\mathrm{y}} & 6.49^{\mathrm{z}} \mathrm{a}^{\mathrm{x}} & 6.51 \mathrm{a} & 6.14 \mathrm{a} & 6.79 \mathrm{a} & 6.04 \mathrm{a} & 6.29 \mathrm{a}\end{array}$

\begin{tabular}{|c|c|}
\hline 500 ppm EtOH:MJ ${ }^{\mathrm{w}}$ & $6.52 \mathrm{a}$ \\
\hline
\end{tabular}

600 ppm EtOH:VN: $\quad 6.13 \mathrm{a} \quad 5.85 \mathrm{~b} \quad 5.10 \mathrm{~b} \quad 6.15 \mathrm{~b} \quad 4.75 \mathrm{c} \quad 5.09 \mathrm{c}$

\section{$\mathrm{CT}: \mathrm{LN}: \mathrm{MJ}$}

${ }^{\mathrm{z}}$ Hedonic scale range 1-9. Score of: $1=$ dislike extremely, $9=$ like extremely, 5=neither like nor dislike.

${ }^{\mathrm{y}} \mathrm{UTC}=$ untreated control; $\mathrm{CT}=$ citral $; \mathrm{EtOH}=$ ethanol; $\mathrm{LN}=$ linalool; $\mathrm{MJ}=$ methyl jasmonate; $\mathrm{VN}=$ vanillin.

${ }^{x}$ Means with the same letter are not significantly different at the $95 \%$ confidence level according to Tukey's HSD Mean Separation Test.

${ }^{\mathrm{w}} 500$ ppm EtOH:MJ = 495.5 ppm ETOH, 4.5 ppm MJ ; 600 ppm EtOH:VN:CT:LN:MJ = 475.5 ppm EtOH, 4.5 ppm MJ, 60 ppm VN, 30 ppm CT, 30 ppm LN. 
Table 7. Individual overwrapped $454 \mathrm{~g}$ clamshell packages: volatile compounds and treatment levels, 2011-2013.

\begin{tabular}{ll}
\hline $\begin{array}{l}\text { Volatile } \\
\text { compound }\end{array}$ & \multicolumn{1}{c}{ Application level $(\mathrm{ppm})$} \\
\hline Ethanol & $50,100,150,200,250,300,350,400,450,500,550,600,650$, \\
& $700,750,800,850,900,950,1000,1050,1100,1150,1200$ \\
Methyl jasmonate & $0.5,3.5,4.5,35,45$ \\
Carvacrol & $5,10,15,20,25,40,50,100,125,200,300,375$ \\
Thymol & $10,25,50,60,100$ \\
Eugenol & $5,10,15,20,25,40,50,100,200,300,375$ \\
Linalool & $5,10,15,20,25,30,35,40,45,50,60,75,100,125,200$ \\
Citral & $5,10,15,20,25,30,35,40,45,50,60,75,100,125,200$ \\
Vanillin & $10,25,50,60,100$ \\
Cinnamaldehyde & 50,150
\end{tabular}




\section{REFERENCES}

Abd-Alla, M.A., M.M. Abd-El-Kader., F. Abd-El-Kareem and R.S.R. El-Mohamedy. 2011. Evaluation of lemongrass, thyme and peracetic acid against gray mold of strawberry fruits. J Agric. Sci. Technol. 7(6):1775-1787.

Agar, T., J.M. Garcia, U. Miedtke and J. Streif. 1990. Effect of high $\mathrm{CO}_{2}$ and low $\mathrm{O}_{2}$ concentration on the growth of Botrytis cinerea at different temperatures.

Gartenbauwissencraft. 55(5):219-222.

Almenar, E., R. Catala, P. Hernandz-Muñoz and R. Gavara. 2009. Optimization of an active package for wild strawberries based on the release of 2-nonanone. Food Sci. and Technol. 42(2):587-593.

Artes, F., J.A. Tudela, J.G. Marin, R.Villaescusa, H. Artes, J. Fernandez, P. Martinez and N. Castilla. 2001. Modified atmosphere packaging of strawberry under selfadhesive films. Acta Hort. 559:805-809.

Arya, A. and A. Pereolló. 2010. Management of fungal plant pathogens. CABI. Oxfordshire, OX, UK.

Ayala-Zavala, J. F., S.Y. Wang, C.Y. Wang and G.A. Gonzalez-Aguilar. 2005. Methyl jasmonate in conjunction with ethanol treatment increases antioxidant capacity, volatile compounds and postharvest life of strawberry fruit. Eur. Food Res. Technol. 221(6):731-738.

Badaboost, M. 2000. Gray mold or Botrytis-blight of vegetables. RPD 942, University of Illinois Extension, University of Illinois, Urbana-Champaign. 13 October 2012. < http://ipm.illinois.edu/diseases/rpds/942.pdf>.

Ben Arfa, A., S. Combes, L. Preziosi-Belloy, N. Gontard and P. Chalier. 2006. Antimicrobial activity of carvacrol related to its chemical structure. Lett. Appl. Microbiol. 43(2):149-154.

Ben Arfa, A., S. Combes, L. Preziosi-Belloy, N. Gontard and P. Chalier. 2007. Antimicrobial paper based on a soy protein isolate or modified starch coating including carvacrol and cinnamaldehyde. J. Agric. Food Chem. 55(6):2155-2162.

Bhaskara Reddy, M.V., P. Angers, A. Gosselin and J. Arul. 1998. Characterization and use of essential oil from Thymus vulgaris against Botrytis cinerea and Rhizopus stolonifer in strawberry fruits. Phytochem. 47(8):1515-1520.

Bixler, H.J. and O.J. Sweeting. 1971. Barrier properties of polymer films. p. 85-127. In: O.J Sweeting (eds.) Science and technology of polymer films, Vol. II. Interscience, NY. 
Blanch, G.P., G. Flores and M.L. Castillo. 2011. Influence of methyl jasmonate in conjunction with ethanol on the formation of volatile compounds in berries belonging to Rosaceae. Postharvest Biol. Technol. 62(2):168-178.

Braun, P. G. and J.C. Sutton. 1987. Inoculum sources of Botrytis cinerea in fruit rot of strawberries in Ontario. Can. J. Plant Pathol. 9(1):1-5.

Bringhurst, R.S., V. Voth and D. Van Hook. 1960. Relationship of root starch content and chilling history to performance of California strawberries. J. Amer. Soc. Hort. Sci. 75:373-381.

Bristow, P.R., R.J. McNicol and B. Williamson. 1986. Infection of strawberry flowers and its relevance to grey mould development. Ann. Appl. Biol. 109(9):545-554.

Browne, W. 1915. Studies in the physiology of parasitism. The action of Botrytis cinerea. Ann. Bot. 29:313-345.

Browne, K.M., J.D. Geeson and C. Dennis. 1984. The effects of harvest date and $\mathrm{CO}_{2^{-}}$ enriched storage atmospheres on the storage and shelf-life of fresh strawberries. J. Hort. Sci. 59(2):197-204.

Bulger, M.A., M.A. Ellis and L.V. Madden. 1987. Influence of temperature and wetness duration on infection of strawberry flowers by Botrytis cinerea and disease incidence of fruit originating from infected flowers. Phytopathology. 77(6):739-744.

Burt, S.A. 2004. Essential oils: Their anti-bacterial properties and potential application in food-a review. Int. J. Food Microbiol. 94(3):223-253.

Burt, S.A. and R. D. Reinders. 2003. Antibacterial activity of selected plant essential oils against Esherichia coli 0157:H7. Letters Appl. Micro. 36(3):162-167.

Cabral, L., V.F. Pinto and A. Patriarca. 2013. Application of plant derived compounds to control fungal spoilage and mycotoxin production in foods. Int. J. Food Micro. 166(1):1-14.

California Strawberry Commission. 2013. About strawberries. 27 October 2013. <http://www.californiastrawberries.com/about_strawberries >.

Camele, I., L. Altieri, L. De Martino, V. De Feo, E. Mancini and G.L. Rana. 2012. In vitro control of postharvest fruit rot fungi by some plant essential-oil components. Int. J. Molec. Sciences. 13(2):2290-2300.

Cerrutti, P., S.M. Alzamora and S.L. Vidales. 1997. Vanillin as an antimicrobial for producing shelf-stable strawberry puree. J. Food Sci. 62(3):608-610.

Chanjirakul, K., S.Y. Wang, C.Y. Wang and J. Sirinphanich. 2007. Natural volatile 
treatments increase free radical scavenging capacity of strawberries and blackberries. J. Sci. Food Agric. 87(8):1463-1472.

Choquer, M., E. Founier, C. Kunz, C. Levis, J.M. Pradier, A. Simon and M. Vlaud. 2007. Botrytis cinerea virulence factors; new insights into a necrotrophic and polyphagous pathogen. FEMS Microbiol. Lett. 277(1):1-10.

Cole, L., F.M. Dewey and C.R. Hawes. 1996. Infection mechanisms of Botrytis species: pre-penetration and pre-infection processes of dry and wet conidia. Mycol. Res. 100(3):277-86.

Creelman, R.A. and J.E. Mullet. 1997. Biosynthesis and action of jasmonates in plants. Ann. Rev. Plant Physiol. Plant Mol. Biol. 48(1):355-381.

Darrow, G. 1966. The strawberry. Holt, Rhinehart and Winston. New York.

de la Peña Moreno, F., G.P. Blanch and M.L.R. del Castillo. 2010a. Effect of (-) and (+)-methyl jasmonate on the bioformation of aroma-active esters of strawberry fruits. Eur. Food Res. Technol. 231(6):829-834.

de la Peña Moreno, F., M.L.R. del Castillo, G. Flores and G.P. Blanch. 2010b. Impact of postharvest methyl jasmonate treatment on the volatile composition and flavonol content of strawberries. J. Sci. Food Agric. 90(6):989-994.

Deighton, N., I.Muckerschnabel, A.J. Comenares, I.G. Collado and B. Williamson. 2001. Botrydial is produced in plant tissues infected by Botrytis cinerea. Phytochem. 57(5):689-692.

Demole E., E. Lederer and D. Mercier. 1962. Isolement et de' termination de la structure du jasmonate de me' thyle, constituant odorant characte' ristique de le' ssence de jasmin. Helv. Chim. Acta. 45(2):675-685.

Dennis, C. and E. Cohen. 1976. The effect of temperature on strains of soft fruit spoilage fungi. Ann. Appl. Bio. 82(1):51-56.

Devaux, A. 1978. Etude epidemiologique de la moississure grise des fraises et essais de lutte. Phytoprotection. 59:19-27.

Dignum, M.J.W., J. Kerlera and R. Verpoorte. 2001. Vanilla production: technological, chemical, and biosynthetic aspects. Food Rev. Intl. 17 (2): 119-120.

Doehleman, G., F. Molitor and M. Hahn. 2005. Molecular and functional characterization of a fructose specific transporter from the gray mold Botrytis cinerea. Fungal Genet. Biol. 42(7):601-610. 
Doss, R.P. 1999. Composition and enzymatic activity of the extracellular matrix secreted by germlings of Botrytis cinerea. App. and Env. Micro. 65(2):404-408.

Doss, R., J. Deisenhofer, H.A. Von Nidda, A.H. Soeldner and R.P. Mcquire. 2003. Melanin in the extracellular matrix of germlings of Botrytis cinerea. Phytochem. 63(6):687-691.

Droby, S. and A. Lichter. 2007. Postharvest Botrytis infection: Etiology, development and management. p. 349-367. In: Elad, Y., B. Williamson, P. Tudzynski, and N. Delen (eds.). Botrytis: Biology, Pathology and Control. Springer, Dorecht, The Netherlands.

Droby, S., A. Eick, D. Macarisin, L. Cohen, G. Rafael, R. Stange, G. McColum, N. Dudai, A. Nasser, M. Wisniewski and R. Shapira. 2008. Role of citrus volatiles in host recognition, germination and growth of Penicillium digitatum and Penicillium italicum. Postharvest Biol. Tec. 49(3):386-396.

El-Kazzaz M.K., N.F. Sommer and R.J. Fortladge. 1983. Effect of different atmospheres on postharvest decay and quality of fresh strawberries. Phytopath. 73(2):282-285.

Food and Drug Administration. 2012. Sec 182.1, Substances generally recognized as safe. 23 April 2012. <http://www.accessdata.fda.gov/scripts/cdrh/cfdocs/cfCFR/ $1>$.

Gloede, F. 1858. Note sur le Fragaria lucida ou Fraisier de Californie. Flore des serres et der jardins de l'Europe. 13:9-10.

Govrin, E.M. and A. Levin. 2000. The hypersensitive response facilitates plant infection by the necrotrophic pathogen Botrytis cinerea. Current Biol. 10(13):751-757.

Guillén, F., P.J. Zapata, D. Martínez-Romero, S. Castillo, M. Serrano and D. Valero. 2007. Improvement of the overall quality of table grapes stored under modified atmosphere packaging in combination with natural antimicrobial compounds. J. Food Sci. 72(3):185-190.

Hajimehdipoor, H., M. Shekarchi, M. Khanavi, N. Adib and M. Amri M. 2010. A validated high performance liquid chromatography method for the analysis of thymol and carvacrol in Thymus vulgaris L. volatile oil. Phcog Mag. 6(23):154158.

Have, A.T., W. Mulder, J. Visser and J.A. Van Kan. 1998. The endopolygalacturanase gene Bcpg1 is required for full virulence of Botrytis cinerea. Mol. Plant Microbe In. 11(10):1009-1016.

Jarvis, W. R. 1962a. The dispersal of spores of Botrytis cinerea Fr. in a raspberry plantation. Trans. Br. Mycol. Soc. 45(4):549-559. 
Jarvis, W.R. 1962b. The infection of strawberry and raspberry fruits by Botrytis cinerea Fr. Ann. Appl. Biol. 50(3):569-575.

Johnson Jr., H.A. 1990. The contributions of private strawberry breeders. Hortscience. 25(8):897-902.

Kader, A.A. 1991. Quality and its maintenance in relation to the postharvest physiology of strawberry. p. 145-152. In: A. Dale and J.J. Luby (eds.). The strawberry into the $21^{\text {st }}$ century. Timber Press, Portland, OR.

Karabulut, O.A., U. Arslan and G. Kuruoglu. 2004. Control of postharvest diseases of organically grown strawberry with preharvest applications of some food additives and postharvest hot water dips. J. Phytopath. 152(4):224-228.

Ke, D., L. Goldstein, M. O’Mahony and A.A. Kader. 2006. Effects of short-term exposure to low $\mathrm{O}_{2}$ and high $\mathrm{CO}_{2}$ atmospheres on quality attributes of strawberries. J. Food Sci. 56(1):50-54.

Ke, D., L Zhou and A.A. Kader. 1994. Mode of oxygen and carbon dioxide action on strawberry ester biosynthesis. J. Am. Hortic. Sci. 119(5):971-975.

Kunkel, B.N. and D.M. Brooks. 2002. Cross talk between signaling pathways in pathogen defense. Curr. Opin. Plant Biol. 5(4):325-331.

Larsen, M. and C.B. Watkins. 1995. Firmness and concentrations of acetaldehyde, ethyl acetate and ethanol in strawberries stored in controlled and modified atmospheres. Postharvest Biol. Tech. 5(1):39-50.

Lawless, J. 1995. The illustrated encyclopedia of essential-oils. HarperCollins, Hammersmith, London.

Maas, J.L. 1998. Compendium of strawberry diseases. $2^{\text {nd }}$ ed. Amer. Phytopathol. Soc., St. Paul, MN.

Mercier, J., M. Kong and F. Cook. 2009. Fungicide resistance among Botrytis cinerea isolates from California strawberry fields. Phytopath. 99(6):S84.

Milos, M., J. Mastelic and I. Jerkovic. 2000. Chemical composition and antioxidant effect of glycosidically bound volatile compounds from oregano (Origanum vulgare L. spp. hirtum). Food Chem. 71(1):79-83.

Mitcham. B. 1996. Quality assurance for strawberries: A case study. Perishables Handling Nwsl. 85:6-9. 
Moline, H.E., J.G. Buta and R.A. Saftner. 1997. Comparison of three volatile natural products for the reduction of postharvest decay in strawberries. Adv. Strawberry. Res. 16:13-18.

Moyls, A. L., P.L. Sholberg and A.P. Gaunce. 1996. Modified-atmosphere packaging of grapes and strawberries fumigated with acetic acid. HortScience. 31(3):414-416.

Mukkun, L. and Z. Singh. 2009. Methyl jasmonate plays a role in fruit ripening of 'Pajaro' strawberry through stimulation of ethylene biosynthesis. Sci. HorticAmsterdam. 123(1):5-10.

Muriel-Galet, V., J.P. Lerisuelo, G. López-Carballo, S. Aucejo, R. Gavara and P. Hernández-Muñoz. 2013. Evaluation of EVOH-coated polypropylene films with oregano essential-oil and citral to improve the shelf-life of packaged salad. Food Control. 30(1):137-143.

Novak, I., E. Zambori-Nemeth, H. Horvath, Z. Seregely and K. Kaffka. 2002. Study of essential oil components in different Origanum species by GC and sensory analysis. Acta Aliment. Hung. 32(2):141-150.

Nunes, M.C.N., A.M.M.B. Morais, J. K. Brecht and S. A. Sargent. 2002. Fruit maturity and storage temperature influence response of strawberries to controlled atmospheres. J. Amer. Soc. Hort. Sci. 127(5):836-842.

Onawumni, G.O. 1989. Evaluation of the anti-microbial activity of citral. Lett. Appl. Microbiol. 9(3):105-108.

Özek, T., N. Tabanca, F. Demirci, D.E. Wedge and K.H.C. Baser. 2010. Enantiomeric distribution of some linalool containing essential-oils and their biological activities. Rec. Nat. Prod. 4:180-192.

Paulus, A.O. 1990. Fungal diseases of strawberry. Hortscience. 25(8):885-889.

Paulus, A.O., V. Voth, F. Shibuya, H. Bowen and A.H. Holland. 1969. Fungicidal control of Botrytis rot in strawberries. Cal. Agric. 23(1):15-16.

Pierterse, C.M., S.C. Van Wees, E. Hoffland, J.A. Van Pelt and L.C. Van Loon. 1996. Systemic resistance in Arabidopsis induce by biocontrol bacteria is independent of salicylic acid accumulation and pathogenesis related gene. The Plant Cell. 8(8):1225-1237.

Plotto, A, D.D. Roberts and R.G. Roberts. 2003. Evaluation of plant essential oils as natural postharvest disease control of tomato (Lycopersicon esculentum). Acta Hortic. 628:737-745. 
Powelson, R.L. 1960. Initiation of strawberry fruit rot caused by Botrytis cinerea. Phytopathology. 50:491-494.

Rattanapitigorn, P., M. Arakawa and M. Tsuro. 2006. Vanillin enhances the anti-fungal effect of plant essential oils against Botrytis cinerea. Int. J. Arom. 16(3):193-198.

Robinson, J.E., K.M. Browne and W.G. Burton. 1975. Storage characteristics of some vegetables and soft fruit. Ann. Appl. Bio. 81(3):399-408.

Rousseau, S. and B. Doneche. 2001. Effects of water activity on the growth of some epiphytic microorganisms isolated from grape berry. Vitis. 40(2):75-78.

Saltveit, M.E. 2004. Respiratory metabolism. 15 November 2013. <http://www.ba.ars.usda.gov/hb66/019respiration.pdf>.

Sanz, C., A.G. Peréz, R. Olias and J.M. Olias. 2006. Quality of strawberries packed with perforated polypropylene. J. Food Sci. 64(4):748-752.

Šegvić Klarić, M., I. Kosalec, J. Mastelić, E. Pieckova and S. Pepeljnak. 2007. Antifungal activity of thyme (Thymus vulgaris L.) essential-oil and thymol against moulds from damp dwellings. Lett. Appl. Microbiol. 44(1):36-42.

Serrano, M., D. Martínez-Romero, F. Guillén, J.M. Valverde, P.J. Zapata, S. Castillo and D.Valero. 2008. The addition of essential oils to MAP as a tool to maintain the overall quality of fruits. Trends Food Sci. Tech. 19(9):464-471.

Snow, D. 1949. The germination of mould spores at controlled humidities. Ann. Appl. Biol. 36(1):1-13.

Sommer, N.F., R.F. Fortlage, F.G. Mitchell and E.C. Maxie. 1973. Reduction of postharvest losses of strawberry fruits from gray mold. J. Amer. Soc. Hort. Sci. 98:285-288.

Stanley, D. 1998. Keeping freshness in fresh cut produce. 23 January 2012. <http://www.ars.usda.gov/is/ar/archive/feb98/fres0298.htm>.

Staswick, P.E., G.Y. Yuen and C.C. Lehman. 1998. Jasmonate signaling mutants of Arabidopsis are susceptible to the soil fungus Pythium irregulare. Plant J. 15(6):747-754.

Ten Have, A., W.O. OudeBreil, J.P. Wubben, J. Visser and J.A. Van Kan. 2001. Botrytis cinerea endopolygalacturonase genes are differentially expressed in various plant tissues. Fungal Genet. Biol. 33(2):97-105.

Thaler, J.S. 1999. Induced resistance in agricultural crops: Effects of jasmonic acid on herbivory and yield in tomato plants. Environ. Entomol. 28(1):30-37. 
Thompson, J. and J. Knutson. 1997. Forced air cooling in clamshell baskets. Perishable Handling Nwsl. 90:29-30.

TransFresh Corporation. 2012. Tectrol revenue calculator. 14 January 2012. $<$ http://www.tectrol-calculator.com/>.

Tripathi, P. and N.K. Dubey. 2003. Exploitation of natural products as an alternative strategy to control postharvest fungal rotting of fruit and vegetables. Postharvest Biol.Tec. 32(3):235-245.

Tsao, R. and T. Zhou. 2000. Interactions of monoterpenoids, methyl jasmonate, and $\mathrm{Ca}^{2+}$ in controlling postharvest brown rot of sweet cherry. HortScience 35(7):12041307.

U.S. Department of Agriculture. 2013. Non citrus fruits and nut: 2012 summary. 1 December 2013.

<http://usda01.library.cornell.edu/usda/current/NoncFruiNu/NoncFruiNu-01-252013.pdf>.

Vallad, G.E. and R.M. Goodman. 2008. Systemic acquired resistance and induced systemic resistance in conventional agriculture. Crop Sci. 44(6):1920-1934.

Valverde, J.M., F. Guillén, D. Martínez-Romero, S. Castillo, M. Serrano and D, Valero. 2005. Improvement of table grapes quality and safety by the combination of modified atmosphere packaging and eugenol, menthol, or thymol. J. Agric. Food Chem. 53(19):7458-7464.

Van Den Berg, L. and C.P. Lents. 1968. The effect of relative humidity and temperature on the survival and growth of Botrytis cinerea and Sclerotinia sclerotiorum. Can. J. Bot. 46(12):1477-1481.

Van Kan, J.A.L. 2006. Licensed to kill: The lifestyle of a necrotrophic plant pathogen. Trends Plant Sci. 11(5):247-253.

Van Kan, J.A.L., J.W. Vantklooster, C.A.M. Wagemakers, D.C.T. Dees and C.J.B. Van der Vlugt-Bergmans. 1997. Cutinase A of Botrytis cinerea is expressed, but not essential, during penetration of gerbera and tomato. Mol. Plant Microbe In. 10(1):30-38.

Voth, V. 1955. Stored strawberry plants. Cal. Agr. 9(2):9-16.

Voth, V. and R.S. Bringhurst. 1958. Fruiting and vegetative response of Lassen strawberries in southern California as influenced by nursery source, time of planting, and plant chilling history. Proc. Amer. Soc. Hort. Sci. 72:187-197. 
Voth, V. and R.S. Bringhurst. 1990. Culture and physiological manipulation of California strawberries. Hortscience. 25(8):889-892.

Vu, K.D., R.G. Hollingsworth, E. Leroux, S. Salmieru and M. Lacroix. 2011. Development of edible bioactive coatings based on modified chitosan for increasing the shelf-life of strawberries. Food Res. Int. 44(1):198-203.

Wang, C.Y., S.Y. Wang and C. Chen. 2008. Increasing anti-oxidant activity and reducing decay of blueberries by essential oils. J. Agric. Food Chem. 56(10):35873592.

Wang, C.Y., S.Y. Wang, J.J. Yin, J. Parry and L.L.Yu. 2007. Enhancing antioxidant, antiproliferation, and free radical scavenging activities in strawberries with essential oils. J. Agric. Food Chem. 55(16):6527-6532.

Wang, S.Y., C.T. Chen, C.Y. Wang and P. Chen. 2007. Resveratrol content in strawberry fruit is affected by preharvest conditions. J. Agric. Food Chem. 55(20):8269-8274.

Wang, S.Y. and W. Zheng. 2005. Preharvest application of methyl jasmonate increases fruit quality and antioxidant capacity in raspberries. Int. J. Food Sci. Technol. 40(2):187-195.

Wells, J.M. 1970. Modified atmosphere, chemical, and heat treatments to control postharvest decay of California strawberries. Plant Dis. Rptr. 54:431-434.

Williamson, B., B. Tudzynski, P. Tudzynski and J.A. Van Kan. 2007. Botyrtis cinerea: the cause of grey mold disease. Mol. Plant Path. 8(5):561-580.

Xiao, C.L., C.F. Chandler, J.F. Price, J.R. Duval, J.C. Mertely and D.E. Legard. 2001. Comparison of epidemics of Botrytis fruit rot and powdery mildew of strawberry in large plastic tunnels and field production systems. Plant Dis. 8(5):901-909.

Yildiz, K. and H. Yilmaz. 2002. Effect of jasmonic acid, ACC, and ethephon on pollen germination in strawberry. Plant Growth Regulation. 38(2):145-148.

Zhang, F.S., X.Q. Wang, S.J. Ma, S.F Cao, N. Li, X.X.Wang and Y.H. Zheng. 2006. Effects of methyl jasmonate on postharvest decay of strawberries and the possible mechanisms involved. ISHS Acta Hort. 712:693-698. 